\title{
The Freshwater Zooplankton of Sri Lanka, with a Discussion of Tropical Freshwater Zooplankton Composition
}

\author{
By \\ C. H. FERNANDO \\ Depariment of Biology, University of Waterloo, Waterloo, Ontario, Canada. \\ N2L $3 G l$
}

\section{Introdection}

At present the species composition, ecology and production of freshwater zooplankton in tropical and sub-tropical regions is poorly known. The available literature usually deals with the systematics and life histories of a few species. However the zooplankton ecology of African freshwaters is better known than that of either tropical Asia or America. For South East Asia there is the classical work of $\mathbb{R}$ uttner (1952) on zooplankton ecology in Java, Sumatra and Bali. There has been in the recent past a renewed interest in zooplankton ecology and some of the work done has been in tropical countries. The present study was begun in 1968 to provide a solid base of systematics for the zooplanktonic groups Rotifera, Cladocera and Copepoda. During this work which has now been completed (Chengalath and Fernando 1973, Chengalath et al. 1973, 1975 ; Fernando 1974), I noted some consistant differences between the composition of limnetic zooplankton in tropical and temporate regions. A detailed analysis of the Sri Lanka zooplankton based on extensive samples collected from 1965-1974 from all parts of the country and all types of habitats is presented. as a background to discussing differences in tropical and temperate freshwater zooplankton. Previously published data is used to substantiate these differences and an attempt is made to explain. the likely reasons for these differences.

The freshwater zooplankton of tropical regions is less diverse than that of temperate regions. Data substantiating this is a vailable in the literature and has been briefly dealt with in a recent review (Fernando 1979). However the reasons for such a difference are not yet clear. It is generally believed that fish predation is the major factor responsible for the paucity of larger zooplanktonic crustacean. species. The present study indicates the reasons are probably much more complex and involve the direct and. indirect effects of temperature, the type of food available and predation by fish and invertebrates. In addition toxic effects of algae and macrophytes may also influence species composition.

\section{Review of Literature}

From a historical point of view the Cladocera and Calanoida of Sri Lanka are of great interest because of the early classical work of Brady (1886), Poppe and Mrazek (1895), Daday (1898a, 1898b), Gurnes $(1906,1916,1931)$ and Apstein $(1907,1910)$. These studies described many widely distributed speciee for the first time and the work of Apstein $(1907,1910)$ was the first limnological study of a sophisticated type done in a tropical country. The knowledge of the freshwater zooplankton of Sri Lanka has been. 
THE FRESHWATER ZOOPLANKTON OF SRI LANKA

further extended by the work of Bàr (1924), Mendis and Fernando (1962), Chengalath and Fernando (1973), Chengalath et al. (1973, 1975), and Fernando (1974, 1978). There are also a number of references to the zooplankton of ricefields: Weerekoon (1957), Fernando (1977) ; small lakes: Mendis (1964, 1965), Costa and de Silva (1969) and Fernando and Ellepola (1969).

The systematics of the freshwater zooplankton (exclusing Protozoa and Chaoborus) are better known for Sri Lanka than any other tropical country. In all 138 species of Rotifera ; 58 Cladocerans and 23 species of freeliving Cyclopoida and Calanoida are known, described and illustrated from local material. There is a considerable literature on the systematics and biology of zooplankton in tropical Africa (Proszynska 1968, Beadle 1974). In South East Asia the only areas studied in detail besides Sri Lanka are Java, Bali and Sumatra (Kiefer 1933, Brehm 1933, Hauer 1938, Ruttner 1952) and the Philippines (Mamaril 1977). There is also some data on Central and South America (Zaret $1972 b$ and Brandorff 1977). Besides these papers are unpublished data from all three continents which will be presented in the present paper. Although the obvious differences between tropical and temperate freshwater zooplankton composition can be gleaned from the literature no detailed analysis of any single tropical region has been attempted and compared for the Rotifera, Cladocera and Copepoda with a temperate region.

The knowledge of zooplankton productivity in tropical freshwaters is meagre. The only detailed data comes from Lake George, Uganda where the zooplankton is dominated by a single Cyclopoida, Thermocyclops crassus (called T. hyalinus). This data is presented in a series of papers (Burgis, 1970, 1971, 1974, Burgis and Walker 1972 and Burgis et al. 1973). Predation on zooplankton by fish and invertebrates has been dealt with by Green (1967) and Zaret $(1969,1972 a, 1972 b, 1975)$ in Africa and South America respectively.

\section{Materials and Methods}

Zooplankton samples were collected with $25 \#,(64 \mu)$ and $10 \#(157 \mu)$ nets and the samples were mixed and concentrated. This method gives a wide representation of even rare species of $\mathbb{R}$ otifera, Cladocera and Copepoda. An attempt was made to obtain concentrated samples by filtering a large volume of water and in deeper lakes by taking both vertical and horizontal samples. In the littoral zone the net was swept among vegetation and close to the bottom to disturb and capture Cladocera and Copepoda living on vegetation and in the fine sediment and debris. All samples were fixed immediately in $5-10 \%$ formalin. Some of the samples studied were collected by Dr. D. G. Frey. Department of Biology, Indiana University, Bloomington, U.S.A. in 1964-1965 and loaned to the author. The whole sample including a duplicate usually was examined with a M5 or M8 Wild Stereoscope and the species enumerated. Temporary preparations were made in Polyvinyl Lactophenol tinted with Lignin pink for confirming diagnoses.

The samples were collected from almost every part of Sri Lanka (Fig, 1). The names of localities and type of habitat are given in Appendix 1. A flexible numerical system has been used to designate localities and sevem habitat types. A list of species identified in each sample on individual sheets of paper have been deposited in the Department of Fisheries, P.O. Box 531, Colombo 3, Sri Lanka.

The samples collected during 1965-1974 have been plotted against the dates of collection (Fig. 2). Samples have been collected in every month of the year. Typical monthly means of rainfall from representative areas of Sri Lanka have also been plotted (Fig. 2). There is some variation in rainfall from year to year but the seasonal pattern and intensity remain relatively stable. The collection 


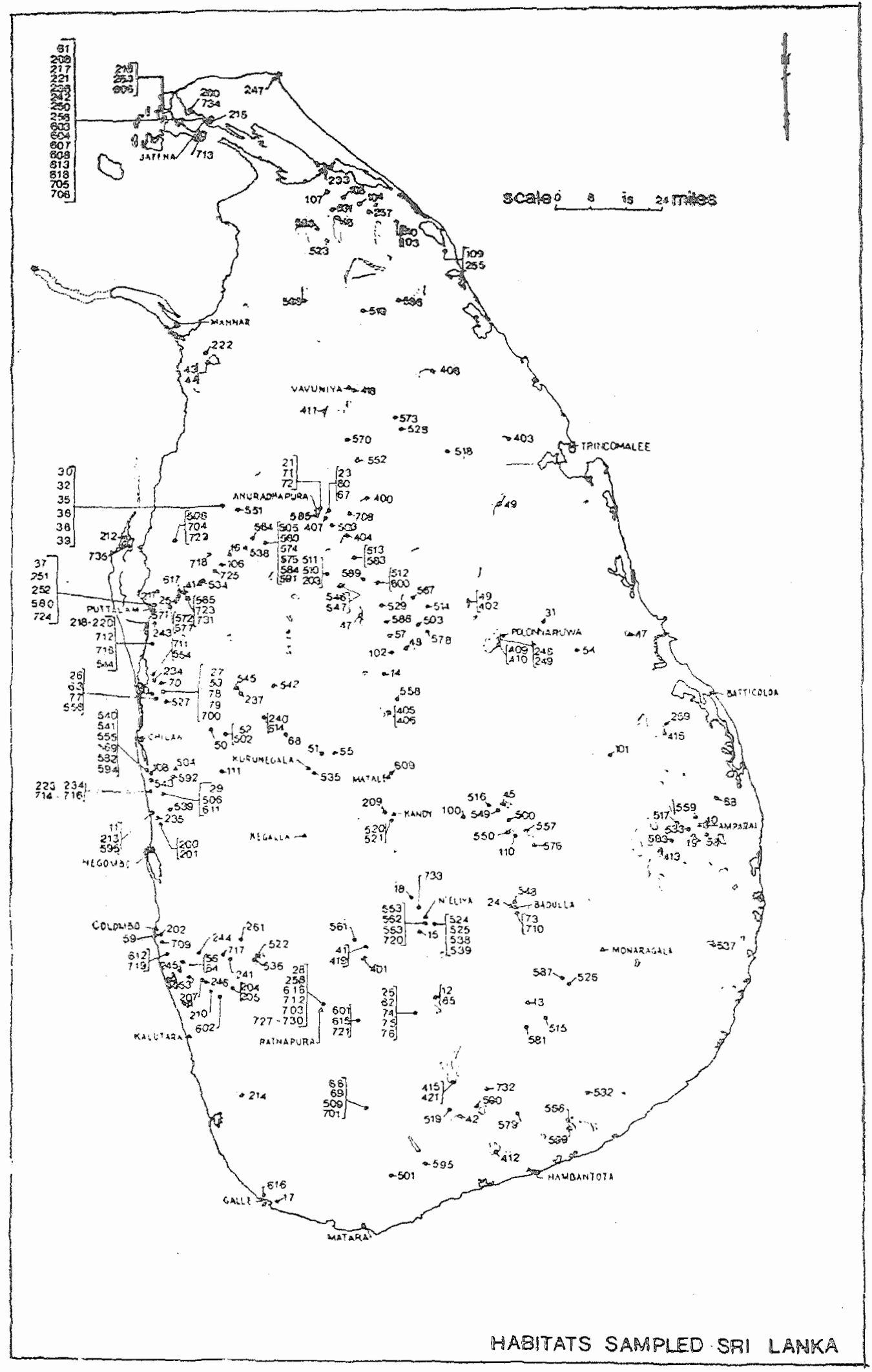

Fig. 1. Collecting localities in Sri Lanka. Numbers designate habitat types. 


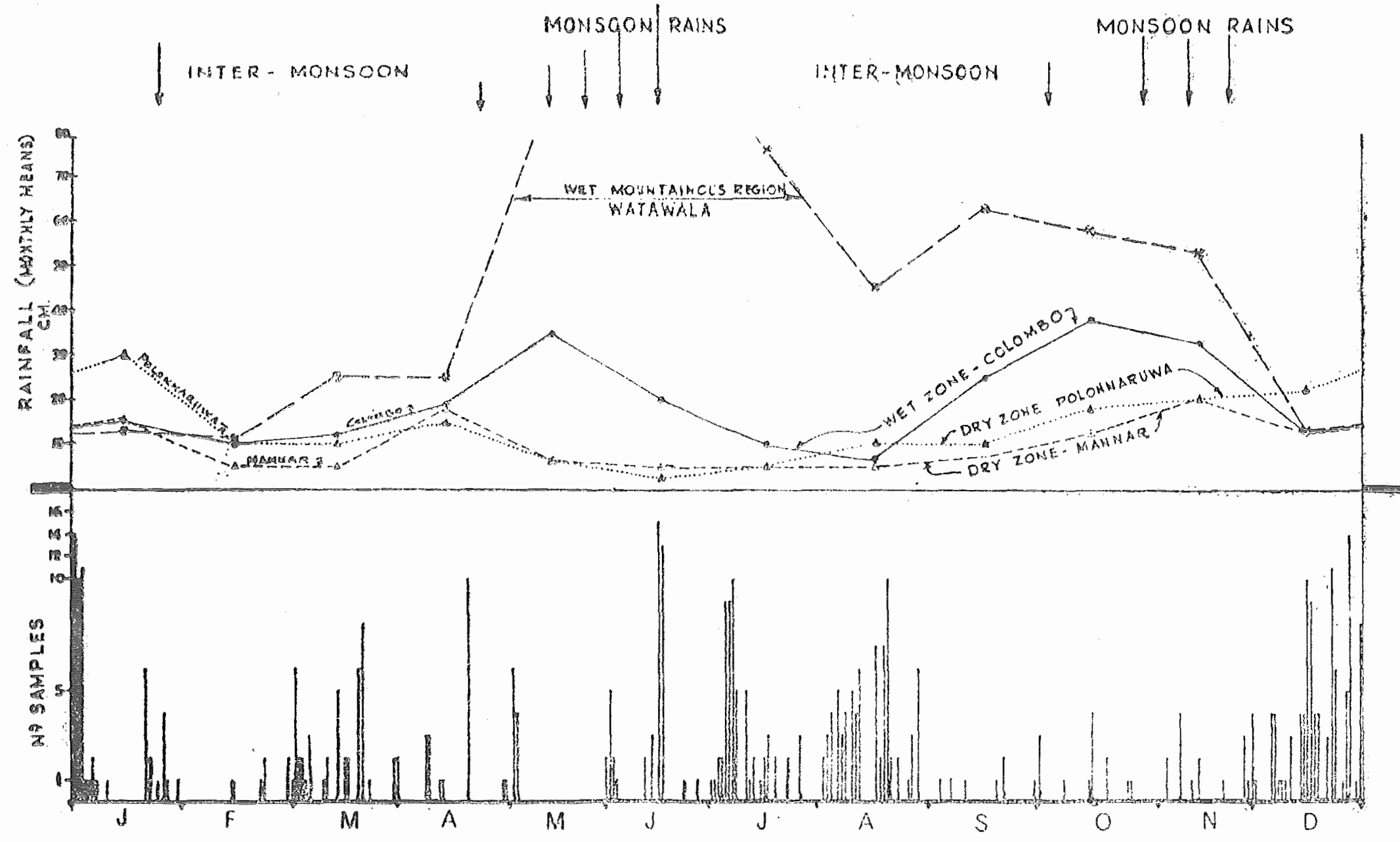


of zooplankton is most difficult during the actual monsoons (April-May and October-November) due to dilution of the fama and the muddy water. In the dry season (January-February and SeptemberOctober) there is no standing water in ponds and only the largest habitats cam be sampled.

Besides the three groups of zooplankton, i.e., Rotifera, Cladocera and Copepoda the othen invertebrates collected were identified to various levels from order to species. These are dealt with later, separately from the zooplankton.

\section{Geology, $\mathbb{P h y s i c a l ~ a n d ~ C h e m i c a l ~ F a c t o r s ~}$}

The basic geological formation in most of Sri Lanka is Pre-Cambrian crystalline rock. There is some Miocene limestone in the North and Northwest and very small areas of Jurassic formations in the Northwestern region (Puttalam) and Sabaragamuwa Province (Ratnapura). A comprehensive accounit of the geology has been given by Cooray (1967). The elevation of the land in Sri Lanka is in the form of three peneplains. The lowest is only slightly above sea level while the highest has an average elevation of about $1,500 \mathrm{M}$. These so-called peneplains (almost plains) were first recognised by Adams (1929) and are the result of erosion of the basic rock formations.

The temperatures prevailing during the year throughout most of the country is typically tropicat and varies from about $24^{\circ} \mathrm{C}-32^{\circ} \mathrm{C}$. However at higher elevations much lower temperatures are recorded with lows of $1-2^{\circ} \mathrm{C}$ below zero in localities like Nuwara Eliya, Horton plains and Mouns Pidurutalagala (elevations about $2,000 \mathrm{~m}$.). Rainfall varies both in quantity and distribution during the year. Two monsoons, the Suuthwest (April-May) and the Northeast (October-November) bring the major portion of rainfall. Some regions (the wet zone) receive rainfall during both monsoons. Other regions receive rain only during one monsoon to all intents and purposes (Fig. 2). There are arid regions in Sri Lanka in the Northern, Northeastern, Northwestern, Eastern and Southern portions of the country.

The water chemistry of Sri Lanka freshwaters has been investigated by a number of workers including Srimanme (1953), Giesler (1967) and Weninger (1972). There is a wide range in $\mathbf{p H}$, calcium content and nitrate and phosphate levels. Slightly acid waters are common in the Southwestern and hilly regions with more alkaline waters in other regions with high calcium levels in the Miocene limestone areas. Pollution by human faeces and agricultural, industrial and household wastes is sometimes quite intense. Tidal influence is very small but the low-lying marshes mear the sea-coast are infilterated by saline water and humic brackish waters are fairly widespread in these areas. The samples collected cover all types of waters in regard to size, chemistry, permanence, temperature regimes and elevation (Fig. 1, Appendix 1).

\section{Freshwater Habidats}

Sri Lanka has a wide and attractive range of freshwater habitats. In the running water category (Fig. 3) are slow-flowing, fast-flowing, temporary and perennial and low and high-elevation rivers and streams. Two recent studies, Brinck et al. (1971) and Costa and Starmuhlner (1972) give detailed descriptions of the physical, chemical and biological features of lotic waters throughout the island. The standing (lentic) habitats have been dealt with in some detail with reference to lakes, by Fernando and Indrasena (1969) and Fernando $(1971,1973,1978)$ and ricefields by Fernando (1977b). There has been considerable human interference with both lotic and lentic waters by damming the former and extending the area of the latter type. Sri Lanka has mo naturallakes and the closest approach to natural lakes are the villus or Varzea type (Reiss 1977) lakes. The extent of man-made lakes in a small area (Fig. 4) and the whole of Sri Lanka (Fig. 5) shows the extent of lnumain interference in the matural aquatic ecosystem. Ricefields form an important component, albeit 3-A 45286 (80/03) 


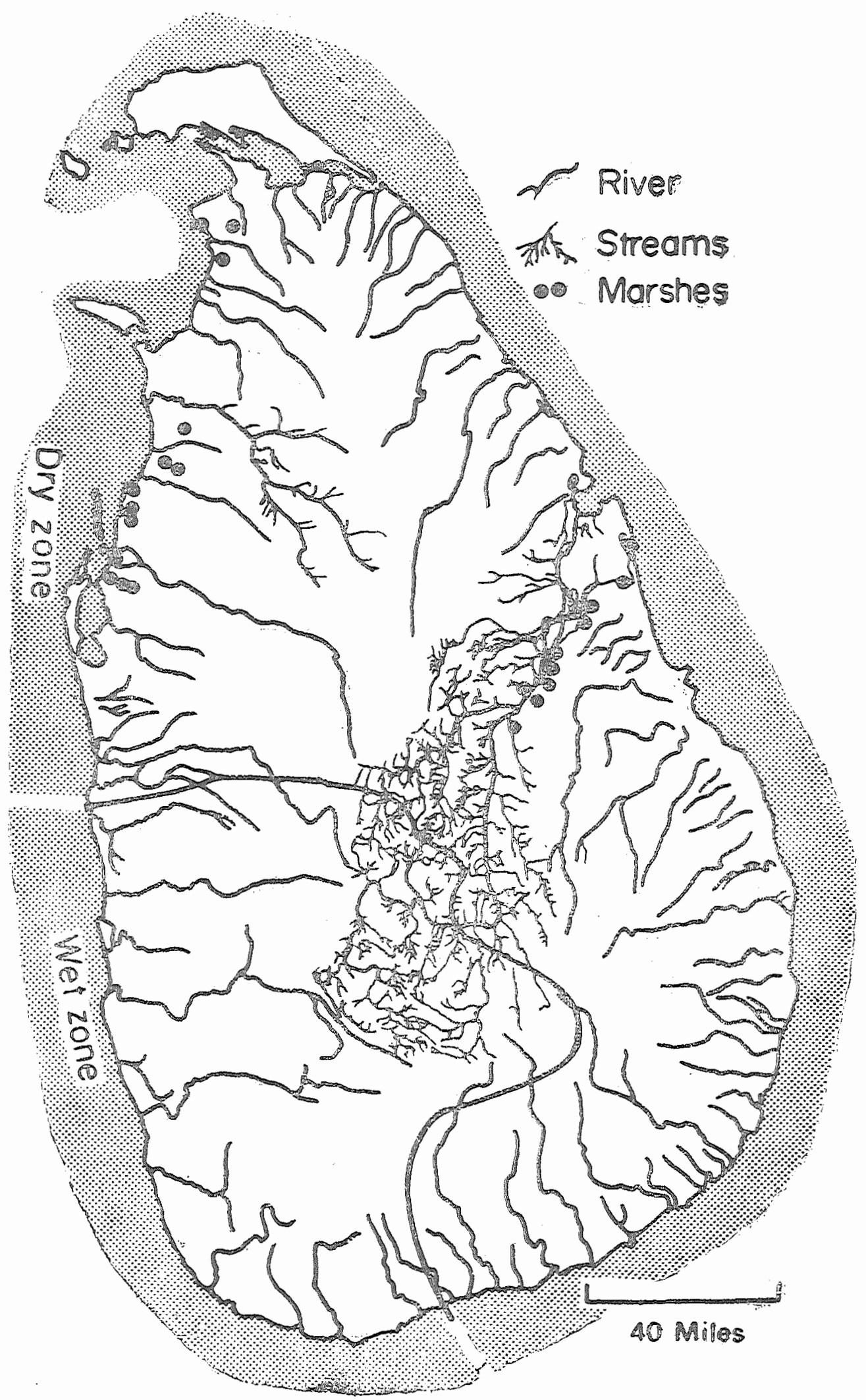

Fig. 3.-- River systens in Sri Lanka. Streams are shown for only two rivers. One in the dry zone and one in the wet zone (After Fernando 1971). 
temporary, of the aquatic ecosystem. There are over 10,000 small reservoirs $(<300$ ha) and about 60 large reservoirs $(>300 \mathrm{ha})$. Together they account for about 170,000 ha (Mendis 1976). Indrasena and Fernando (1969) and Fernando (1971, 1973) have classifed the reservoirs and listed the larger ones. Fernando (1971) allso estimated the extent of lotic and lentic waters. One of the characteristic features of reservoirs is the great change in water level throughout the year. This has been illustrated for large and small reservoirs by Fernando (1973).

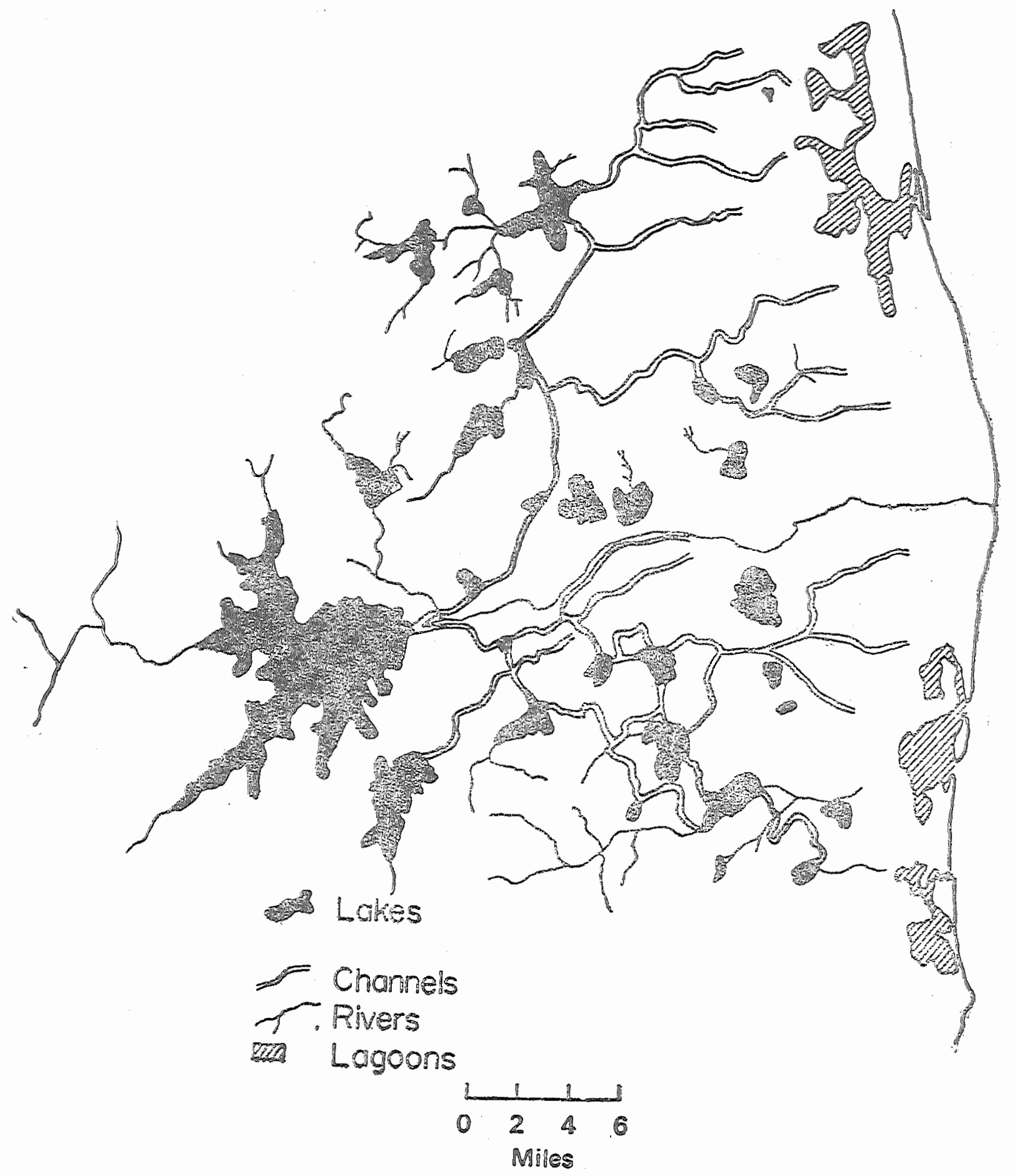

Fig. 4.-The Galoya multipurpose scheme showing the extent of human inierference with the natural aquatic habitats by construction of reservoirs and channels (After Fernando 1971). 


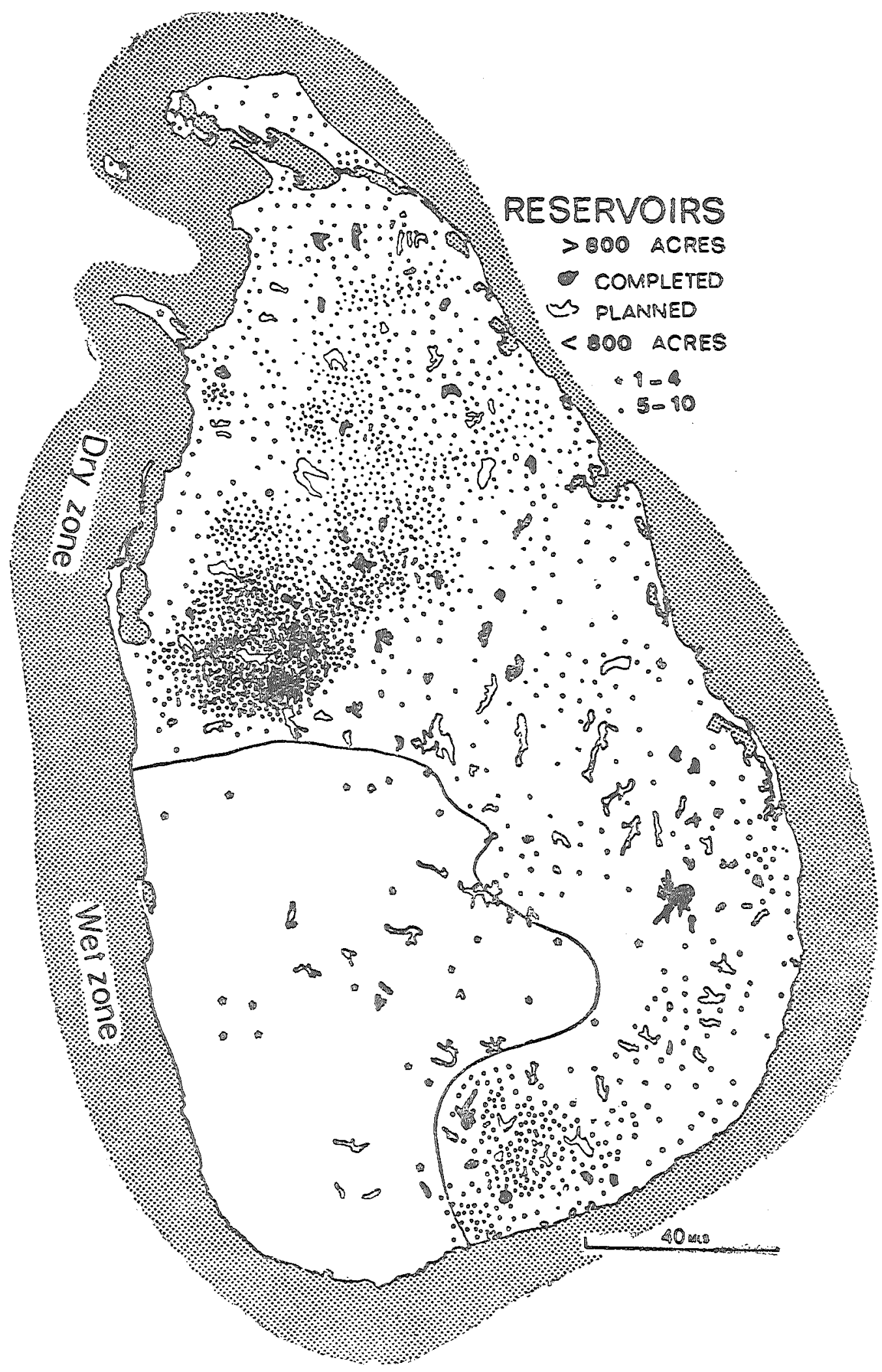

Fig. 5.-Man-made lakes in Sri Lanka (After Fernando 1971)。 
In Sri Lanka where rainfall is relati ly abundant there are numerous ponds of varying degrees of permanence. During the floods which follow the monsoon rains these ponds merge into extensive sheets of water. In some of the more arid areas the ponds are very temporary. These areas have characteristic faunal ellements like Anostraca (no Notostraca occur in Sri Lanka), Conchostraca and. large Calanoida. Few of these are recorded in the material studied because of the wery short-lived nature of these ponds and their fauna.

Resulutes

The zooplankton identified in 473 samples have been listed under seven types of habitat (Tables 1 and2). Besides the Rotifera, Cladocera and Copepoda listed in Tables 1 and 2 the other invertebrate collected. with the zooplankton are listed in Table 3.

The term zooplankton is used in the present paper to include the Rotifera, Cladocera and Copepoda for purposes of detailed study and discussion. An attempt is made to separate limnetic and non-limnetic plankton. The samples from reservoirs $>300$ ha are considered linmetic but this is not strictly true. During the dry season these reservoirs are often quite sifallow and thein margins are invaded by vegatation. Although the samples were taken in open water, littoral species would predominate under these circumstances in some instances.

The percentage occurrence of all species recorded is listed under the seven types of habitats (Table 1). To separate very common species a level of $25 \%$ occurrence in any one type of habitat is considered appropriate. This species list and their percentage occurrence is given in Table 2. To show the degree (percentage) of similarity in species composition between the different types of habitats (excluding miscellaneous), a series of denoirograms was consiructed using the coefficient Sj or Jacard coefficient (Jacard 1908, Sneath and Sokal 1973). Sj=NJK/NJK $+N J k+N j K$, whəre $\mathbb{N} J \mathbb{K}=$ mumber of species present in both labitats $J$ and $\mathbb{K}$. NJK=number of species present in $J$ but absent in $\mathbb{K}$ and $\mathrm{NjK}=$ number of species present in $\mathbb{K}$ but absent in $J$.

\section{Gemeral Remarks}

(a) Rotiferc.-As expected there is a very wide range in the occurrences of the different species. Those below $2 \%$ total in all types of habitats are considered rare. There are fifteen such species. On the other hand forty species occur in six or all seven types of habitats. These can be considered eurytopic. However many rotifers can be labelled as fugitive species having a capacity to disperse rap.dly. When this is combined with their ability to reproduce rapidly at the high prevailing temperatures; it is not difficult to understand that many rotifers are wide-spread. It is difficult to draw the line between opportunistic species (McArthur 1960) which show a great propensity for increase in numbers and eurytopic species which are tolerant of a wide range of ecological conditions. Many Rotifera probably belong to both categories. Small and rare species are, of course, more likely to be missed in the enumeration. Thus the occurrence of these species has been underestimated.

The composition of the Sri Lanka Rotifera fauna is quite typical of tropical regions. There is a dominance by the genus Brachionus in the limnetic samples especially. Some typically temperate region genera are rare e.g. Keratella (except for $K$. tropica) or absent like the genera Synchaeta, Notholca and Pleosoma. Trichocera and Testudinella are relatively common and there is a profusion. of I.ecane species. The latitudinal variation of planktonic Rotifera and the Brachionidae have been. discussed by Green (1971) and Pejler (1977) respectively. The Sri Lanka fauna fits into the tropical category in-most respects but a so-called temperate species Keratella earlinae which according to Pejler. 
(1977) occurs only in the Nearctic region occurs in Sri Lamka too. Also Kellicotia Longispino which is supposed to occur almost exclusively in temperate regions (Pejler 1977) also occurs in Sri Lanka. However Brachionzs domeri a species endemic to the Indian region occurs not unexpectedly in Sri Lanka; so does Trochosphaera aequtorialis a species with a wide but spotty world distribution.

(b) Clodocera. - The cladoceran fauna is typically tropical with some features unique to Sri Lanka. First of all, like all tropical regions the total cladoceran fauna is of the order of 60 rather than 90-100 of temperate regions (Table 4). This difierence in species numbers is due to the total absence of the families Leptodoridae, Holopedidae and Polyphemidae and the very small number of Daphnios spp., Pletroxus spp. and Ceriodaphnia spp. There are typically tropicall species like Chydorus barroisi, Ch. eurynotus, Dadaya macrops, Ceriodaphnia comuta, Grimaldina brazzai, Indialona spp. and some others However in Sri Lanka the genera Acroperus and Camptocercus foumd in neighbouring tropical countries (India, Malaysia, Indonesia) are absent. Two species Graptoleberis testudinarid and Indialona macronyx previously recorded were not found during the present study.

\section{Cyclopoid and Calanoit Copepoda}

Eleven Cyclopoida were recorded (Table 1). They are all well known and widely distributed except for Microcyclops moghulensis. All are cosmopolitan, tropical or widely distributed except for Tropocyclops confinis which was found only at high elevations. The eleven species of Calanoida recorded includes one giant calnoid Megadiaptomus hebes (Fernando and Hanek 1976) and a species not recorded in the present study namely Paradiaptomus greeni. Only one species is at all common, namely, Phyllodiaptomus annae.

\section{Harpacticoida}

Two widely distributed species Elaphiodella bidens decorata and $\mathbb{E}$. grandidiers were found together with what appears to be the endemic Altheyella cingalensis (Table 1).

\section{Introtingtion and Elimimation of Species}

Poppe and Mrazek (1958) recorded Leptodora kindtii (Focke) in Sri Lanka. This is very likely an introduction with temperate fisis (trout) introductions. Ieptodora kindtii has never been recorded subsequently. Kellikottia bostonienis and Keratella earlinae considered temperate species were recorded in Sri Lanka. Pejler (1977) supports the suggestion that Kellikottia bostonierssis (Rousselet) has been introduced into Sweden with issh (Armemo et al. 1968). It is possible that this species and the Nearctic species Keratella earlinae have been introduced into Sri Lanka.

Daday (1898a) recorded Graptoleberis testudinaria and described Indialona macronyx from Sri Lanka. These species and Paradiaptomus greeni recorded by Gurney (1931) were not found in the present study in spite of extensive sampling. Groptoleberis testudinaria is a rare species in the tropics. Indialona macronyx is rare. Only two published records of this species are known (Smirnov 1972). It has been recently recorded in the Philippines (Mamaril 1977) and in Malaysia (unpublished) from marshes. Its rarity in Sri Lanka is probably due to the great reduction in area of marshes and pollution of existing ones. Fernando (1977) attributed the low diversity of zooplankton in South Indian ricefields to the elimination of marshes.

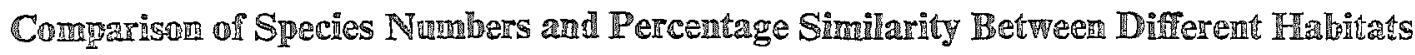

The lowest numbers of species were recorded in villus (flood lakes) and rivers and streams. Both these types of habitats are rumning waters during part of the year at least and hence the paucity of planktonic species is to be expected. Also it should be noted that these habitats were sampled the least (Table 1). Ponds and small reservoirs had the richest faunas. Large reservoirs had less species than 

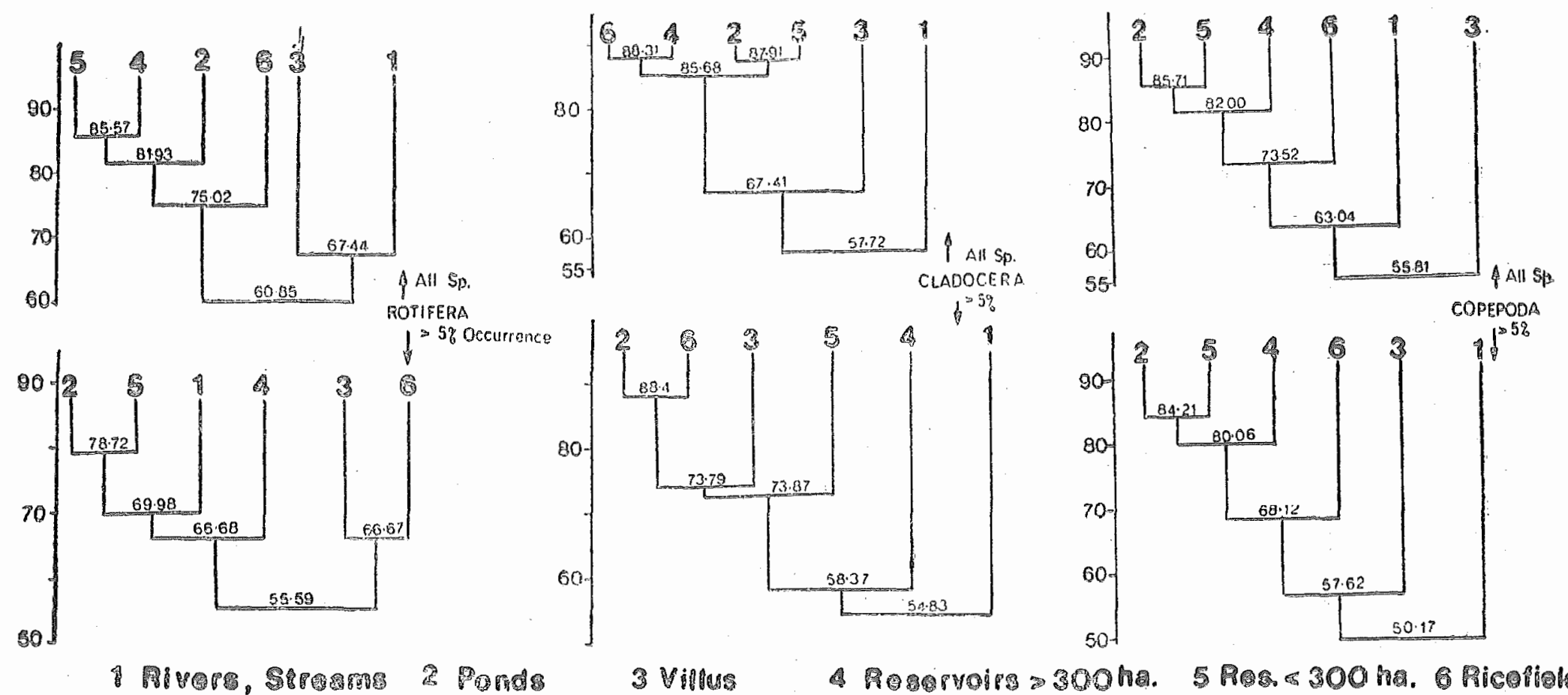

Fig. 6.-Dendrograms of percentage similarity of six types of habitats in regard to the occurrence of Rotifera, cladocera and Copepodo. Jaccard's coefflcient. $\mathrm{Sj}=\mathrm{NJK} / \mathrm{NJK}+\mathrm{NJK}+\mathrm{N} J \mathrm{~K}$ is used (see text). 
small reservoirs and ponds. The littoral component in the fauna is reduced and the open water components increased in large reservoirs. Small reservoirs have a combination of litoral and limmetic* species. Ponds had the highest number of species except in the Rotifera where small reservoirs Which combine the features of littoral and limnetic situations had the largest number of species. Shallow water, i.e. littoral and bottom dwelling "zooplanlton" seems to be far more numerous in species; hence ricefields and miscellaneous habitats, which were generally small, man-made habitats, had quite diverse faunas similar to ponds and have more species than rivers, streams and villus.

A coeficient of the percentage similarity in species composition of the different types of habitat (excluding miscellaneous) has been constructed. The three groups of zooplankton are treated independently and also one coefficient is calculated using only species occurring in $>5 \%$ of that particular habitat. This is done to exclude fugitive and rare species (Fig. 6).

In general it can be said that reservoirs and ponds are more similar than the other types of habitats (Fig. 6). However the distinction is not clearcut by any means. This is due to two factors: (1) Because in tropical freshwaters there are relatively few limnetic species (Table 2), and (2) Even the large reservoirs are often shallow and have a major littoral plankton component which is numerically dominant. There is also in Rotifera a large number of fugitive species. All these factors contribute to an eveness of the zooplankton in all types of habitats in Sri Lanka. Ruttner (1952) mentions that the zooplanktom of tropical regions resembles pond plankton of temperate regions. It resembles even more tropical pond plankton. Lakes and ponds share the same species essentially as there is only a very small percentage of zooplankton species present predominantly in the limnetic region. Proszynska (1963) showed that there was a pond type and a small water body type of Copepoda and Cladocera based on temperate region records only. She defined ponds as having a uniform bottom cover of aquatic plants and no summer thermocline whereas small water bodies had a summer thermocline and a mosaic of bottom vegetation. In the tropical region a thermocline (except diurnally) is not formed in small water bodies or ponds in summer. The present results (Tables 1 and 2, Fig. 6) do not show a distinct group of Cladocera and Copepoda, one for ponds and the other for small water bodies (i.e. reservoirs $<300$ ha!

\section{Iuimetic $\mathbb{Z}$ ooplamirtom}

Reuttner (1953) im discussing the composition of plankton mentions that the pelagial was originally colonized from the shore (littoral). He records the "advance" of littoral forms into the plankton (pelagial) in Sumatran lakes. He found Simocephalus serrulatuss and Latonopsis australis comprising the major portion of the plankton in Lake Manindjau. There is no strict dividing line between littoral and pelagial zooplankton and a species may be predominantly pelagial in one region (Moina micrura in tropical lakes) littoral in arid areas and less often pelagial (European lakes). However most species can be designated planktonic (pelagial) or littoral in a particular area by considering their predominance in littoral or pelagial situations.

Limnetic zooplankton (what few species there are) can be expected to predominate in reservoirs $>300$ ha. There are only a very few species which are commoner in the large reservoirs than in other types of habitats (Tables 1 and 2). Using a level of $25 \%$ occurrences as indicating " common ", eleven species of Rotifera, four of Cladocera and three of Copepoda can be considered in this category.

* The terms limanetic and litioral species are used rather loosely but designate forms found predominanty in these situations. 
Of these eighteen species all except Lecane bulla are commoner in large reservoirs than in other types of habitats. However most of them are eurytopic except Hexarthra intermedia and Filinia opoliensis. It is clear that the so-called plankionic Rotifera, Cladocera and Ccpepcca in Sri Ianka lakes are largely if mot wholly composed of eurytopic species commonly found also in ponds. The Rotifera show the largest number of species which can be considered predominantly limnetic.

The number of limnetic zooplankton species in Sri Lanka is thus much smaller than that of temperate regions. In Ontario, Canada, Brandlova et al. (1972) recorded eighteen species cf limretic Cladocera and more recently Smith and Fernando (1978) found 18 species of limnetic Cyclcpoida and Callanoida in Ontario which rarely occur in ponds. Tonolli (1962) found more typically limmetic Rotifera in a single lake than in all the Sri Lanka samples. Changalath, Fernando and George (1972) in a study of planktonic Rotifera of Ontario listed sixty species. Of these almost half are predominantly limnetic in occurrence. Similar figures can be quoted for other temperate regions for the Cladocera, Copepoda and Rotifera.

\section{Species Composition of Tropical Freshwater $\mathbb{Z}$ oondanktom}

The limnetic zooplankton of Sri Lanka is typical of tropical limnetic zoosiankton in species composition. The Rotifera are dominated by members of the genus Brachionus and Keratella tropica. This assemblage has been noted on a worldwide scale by Green (1971) and Pejler (1977). The total number of "planktonic" Rotifera species in Sri Lanka (Circa 89 including Lecane) in reservoirs $>300$ ha.) is similar to figures quoted for some temperate lakes by Green (1972). In the Cladocera however there is a marked difference in the number of limnetic species in tropical as compared to temperate regions. The dominant limetic Cladocera in the tropics consist of Ceriodaphnia comuta, Diaphanosomas (usually $D$. excisum, less commonly $D$. sarsi, D. modigliani) and Moina micrura. AIl these are eurytopic species occurring in a wide range of habitats. They are referred to under many names, e.g. Ceriodaphnia rigaudi (see Rzoska 1956), Moina dubia (see Goulden 1968) and Diaphanosoma singalense and $D$. paucispinosum (V. Koirnek, personal communication). Also these species are the dominant species in the Potamoplankton of the Rivers Nile, Sokoto and Niger in Africa (Brook and Rzoska 1954, Green 1962 and Clarke 1978) in the Mekong (Blache 1959) and the salt lakes in Bengal, India (Seymour Swewl1 1934). Brehm (1933) found these three species and very few others in the limnetic zooplankton in Indonesia. Burgis et al. (1973) found Moina micrura, Ceriodaphnia cornuta and a small Daphnia, D. barbato dominating numerically the Cladocera in Lake George, Uganda. Greem (1967) found onlly Diaphonosoma excisum, Ceriodaphria (2 spp.), probably including C. cornuta, Moina micrura and Daphnio lumholtzi in the stomach of planktivorous fish in Lake Albert. East Africa. A small species of Daphnic, e.g. D. lumholtzi or D. barbata and Bosminopsis dietersi and Bosmina longirostris sometimes occur in limnetic zooplankton in the tropics. Unlike the widely Gistributed, eurytopic forms mertioned earlier these species seem to be predominantly limnetic in occurrence. Brandorff (1977) found a slightly different mix of Cladocera cosmotropical (4 species), Cosmop Jitan (1 species) and Neotropical (5 species) in an Amazon Lake. But again Daphnio was represented by only $\mathbb{1}$ species. In Table $5, \mathbb{I}$ have compiled a list of the limnetic Cladocera occurring in South-East Asian lakes. The dominance of the few species mentioned earlier is quite evident. In Table 4, I have compared the composition of Tropical and Temperate region Cladocera faunas and the limnetic species in the two regions. There are to begin with fewer species of Cladocera in tropical regions than in temperate regions. This is not du. to lack of study of tropical Cladocera since intensive collecting has been done in Indonesia (Brehm 1933), Sri Lanka (Fernando 1974), Philippines (1977), Mamaril and Malaysia and. India (unpublished data). The smaller species number in trcpical lakes is laregly due to the almost total absence of the genus Dophrios so prominent in temperate region 
zooplankton. The members of the families, Holopedidae, Leptodoridae and Polyphemidae are also extremely tare in the tropics. The genera Ceriodaphnia and Bosmina are represented by more limnetic species in the temperate regions than in the tropics. On the other hand the genus Diaphonosoma is represented by more limnetic species in the tropics than in temperate regions where Diaphanosoma brachycum is the omly species in the zooplankton. Moina micrura usually a pond species in arid and temperate regions is commonly found in the limnetic region of tropical lakes (Goulden 1968).

The Copepoda species commonly found in the limnetic zone of tropical lakes are aiso relatively limited in mumber as compared to temperate regions. In South-East Asia Themocyclops crassus and Mesocyclops lecukarti are by far the commonest cyclopoids (Table 4). A similar situation has been reported for Lake George, Uganda by Burgis (1971) and Burgis et al. (1973). In tropical South America, Brandorff (1977) found only three cyclopoids in a lake. Also in general there are few calanoid species even in large lakes in South-East Asia. Lake Toba has only one species, Tropodiaptomus doriae (Kiefer 1933). Lake Lanao has only two species (Frey 1969, Mammaril 1977). I have compiled the occurrence of Cyclopoid Copepoda in a wide range of South East Asian lakes. The dominance of the two cyclopoids Thermocyclops crassus and Mesocyclops leuckarti and the lack of a wide species spectrum is quite evident.

\section{IVumbers of Iimmetic Species and their Size}

The number of zooplankson species occurring in a limnetic region in any lake varies considerably. In 27 Colorado lakes Pennak (1957) found 1-3 Copepoda, 1-5 Cladocera and 1-10 Rotifera. In 42 lakes cutsides the United States but lccated manily in temperate regions, he states that the mean number of Copapoda is 2.7 Cladocera 2.8 and Rotifera 5.5. These figures could well apply to tropical lalres. However there is a major difference when tropical and temperate lakes are compared. The total spacies spactrum of tropical limnetic zooplankton is certainly much smaller in the Cladocera and Copepoda.

From the data presented it is evident that the species spectrum of limnetic Cladocera and Copepoda is much more limited in the tropics than in temperate regions. Most of the tropical data comes from South-East Asia and Africa. The South American data give essentially the same picture but the data available is much more limited. There is however a wealth of data from temperate lalles for comparison, e.g., Scourfield and Harding (1966) and Brandlova et a1. (1972). The commoness of the genus Daphnia is accepted almost universally by temperate region limnologists. Baudouin and Scoppa (1974) mention that Daphnia is conmon everywhere in suggesting it as a suitable assay organism. Ivlev (1937) considered Daphnia the most important food for planktivorous fish and Galbraith (1975) used the large Daphnia as indices of ashing quality for rainbow trout. Yet Daphnia is missing or very rare in tropical countries. Only two small cyclopoid Copepoda and one or two regionally different Calanoida seem to occur in nost tropical regions.

If we compare the size spectrum of limnetic Cladocera and Copepoda from tropical and temperate regions, again we see a marked difference between the two regions. The lower end of the size range is occupied in both regions by Cladocera like Bosminopsis dietersi and Bosminc Spp. (Circa 0.4 mm in length). The largest tropical Cladocera are Daphnia humholtzi and Diaphanosome spp. (Circa $1.3 \mathrm{~mm}$ in length) while in temperate regions the Daphnic spp. often found in the zooplankton measure up to $5 \mathrm{~mm}$ in length and generally $2.5-3.0 \mathrm{~mm}$ in length. Both the common cyclopoids in tropical lakes are also $<1.3 \mathrm{~mm}$ in length, much smaller than their temperate counterparts (see) Burgis et al.1973). The calanoids which are rare in lakes in South-East Asia may measure upto $\mathbb{1} .8 \mathrm{~mm}$. in length including the furca. 
The species size and spectrum of limnetic Cladocera and Copepoda is markcaly smaller in the tropical region than in the temperate regions. The size spectrum is restricted at the upper 6 nd of the scale in tropical zooplankton communities. This applies mainly to the Cladocera and to a lesser extent perhaps to the Copepoda. An attempt will be made to explain these cifferences by considering the likely factors influencing species and size composition of the zooplankton.

\section{Factors influencing Species and Size Composition}

There are a number of factors which in difiexing combination could account for the species and size composition differences between temperate and tropical zooplankton. The most obvious factors involved are food and temperature. This includes direct and indirect effects. Predation by vertebrates and invertebrates has also been showin to have a marked impact on size and species composition of zooplankton. Also size infinences predation.

Daphnia spp. differ greatly in prominence. In temperate regions they comprise one of the dominant zooplankton groups and in the tropics they are relatively insignificant. Also Daphnia has been studied extensively both in the field and in the laboratory. Daphnia spp. are filter feeders In tropical lakes there is often a predominance of large bluegreen algae. Burgis (1973) mentions that filter feeding Cladocera in Lake George, Uganda may be limited by lack of small algal particles. However this would apply to most Cladocera including the genera Ceriodaphia, Diaphanosoma and Moina. Also Lewis (1974) found that in Lake Lanao, Philippines oniy $19.3 \%$ of the cell volume consisted of blue green algae. No Daphnia occur in Lake Lanao, Lake Towwiti, Lake Pozo and Lake Toba, the only large natural lakes in South-East Asia. Temperature has many direct and indirect effects on the survival and abundance of Daphnia. Buros and Rigler (1967) found that the feeding efficiency of Daphnic rosea increases with temperature up to $20^{\circ} \mathrm{C}$ and then fell rapidly. Hall (1964) and Bell and Ward (1970) found that Daphnia pulex moves to the cooler regions of the lake when the temperature rises above $20^{\circ} \mathrm{C}$. The fecundity of Daphnia pulex was shown to peak at $15^{\circ} \mathrm{C}$ and fall at higher temperatures (LeSeur 1960). Although no generalization can be made based on evidence for all temperate regions Daphnia spp. it seems likely that higher temperature is an important factor limiting them to their present range. Also it has been shown that feeding efficiency in Daphnia increases with increasing size (Burns and Rigler 1967) but the optimum size decreases with the rise of temperature (Lynch 1977). These results of the role of temperature and size have been substantiated by ofher workers namely Nawwereck (1959), Hall (1964), Hall et al. (1970) and Haney (1973). In the tropics the larger Daphnia would be selected against by the higher prevaining temperatures tiroughout the lake by lowering fecundity and reducing feeding efficiency. It is a fact that the species of Daphnia found in limnetic regions in the tropics are of small size. Burgis et al. (1973) ccmments on the small size of the Cladocera in Lake George, Uganda and mentions that the Lafhnia sp. presert, D. barbata is only slightly over $1 \mathrm{~mm}$ in length. A common limnetic Dafhnia sp. found in the tropics (and the subtropics) is Daphnia lumholtzi. It is about $1.3 \mathrm{~mm}$ long as compared to the large Daphria spp. in temperate regions which measure from 2.5-5 mm in length (see Brooks 1957, 1963 and Scourfield and Harding 1960).

Two recent reviews by Hall et al. (1976) and Lynch (1977) discuss size selection of zooplankton by predators and the size efficiency hypothesis. Precation by fish on the larger zooplanktons has been documented by Hrbacek (1962), Brooks and Dodson (1965), Galbraith (1967) and Well (1970) besides many other workers. The predation on smaller prey in the zooplankton by invertebrates has been dealt with by Monakov (1972, 1976) and by many workers including Brandl and Femando (1974, $1975 a, 1975 b, 1978)$. Zaret (1975) has discussed the strategies of existence of tropical zooplankton. 
The effect of intensive fish predation on zooplankton is stabilization of the prey size at the lowest level where survival is possible. On the other hand invertebrate predators feed on smaller individuals increasing the premium on rapid growth to as large a size as possible. In tropical lakes small size probably has an advantage due to prevailing high tempratures adversely affecting the larger Eaphnia spp. The situation existing in tropical lakes is certainly a complex balance between various factors. Behaviour and pigmentation play an important part in predator-prey interaction: (Zaret 1972a, 1972b. 1975). Increase in size by spines, helmets and horns have beer resorted to by Rotifera (Gilbert and Waage 1967, Green et al. 1976, : Cladocera (Green 1967, Zaret 1969,. When two "size forms" of a species occur together there is often selective predation on one "size form " (Green 1967, Zaret 1969, Brandl and Fernando 1978). The smaller forms were shown to have a higher predation but olso a higher fecundity by Green (1967) and Zaret (1969).

The smaller species spectrum of tropical zooplankton in the case of Cladocera is probably due largely to higher temperatures influencing negatively the larger Daphnia species which form a major component of temperate zooplankton. The uniform temperatures existing throughout the year would also not favour a diversity of zooplankton species in general. There is predation of large zooplanktom spacies by fish and smaller zooplankton by invertebrates. In the tropics the size spectrum of prey is much smaller than in temprate zooplankton. This is generally believed to be due to intense fish predation on zooplankton in the tropics. While this may occur due to higher activity of the fish and other factors it seems to be more likely that the upper portion of the size spectrum is limited by other factors as discussed earlier. An important consequence of this limitaticn of size specirum is perhaps a higher competition by fish and invertebrate predators for the prey zocplankton. Burgis (1974) found that the production of the dominant zooplankton in Lake George, Uganda, Thermocyclops crassus was not particularly high when compared to the prcduction of crustacean plankton specis in temperate regions. It is possible that the zooplankton production in trcpical lakes is iow in general compared to that of temperate lakes. It is allso noteworthy that Themocyclops crassus feeds on blue green algae which is not eaten by Dapiania barbata in Lake George, Uganda (Moriarty et al. 1973). Some blue green algae may be toxic to zooplankton (Lefevre 1950). Higher plants and blue green algae may inhibit rotifers (Hasler and Jones 1949, Edmondson 1965). Hence the ability to feed and assimilate blue green algae and withstand their toxicity are perhaps of major importance to tropical zooplankton in shallow lakes especially.

The restriction of limnetic cyclopoid copepod species in any tropical region to two or three species only may be influenced by their ability to feed on blue green algae or be carnivorous like Mesocyclops leuckarti. Also the even high temperatures may reduce species diversity and eliminate cold water species in the same way as in Daphnia spp. and crustacean zooplankton in general.

It is interesting to note that the larger Daphnic spp. return to the limaetic zooplankton in the subtropical region and are also present in ponds in these regions. In Lahore, Pakistan, Arora (1931) found four species of Daphnia. In Pokhara, Nepal Daphria lumholtzi and $D$. longispina are both present in a single lake (unpublished data). In $\mathbb{R}$ ajasthan, India, Biswas (1971) records three species of Daphnia and five species in Simla hills, India (Biswas 1966). In Lake Kariba (Zambia-Rhodesia), four species of Daphnia were recorded and in Cuba also four species of Daphnia occur. Shirota (1966), records four Daphnia spp. in Suuth Vietnam. In more tropical areas like Surinam and Volta Lake, Ghana no Daphnia were found (data supplied by Dr. V. Korinek, Charles University, Prague). Also in sub-tropical regions "temperate" species like Daphnia nagna; D. longispina, D. hyalina occut concurrently with the tropical limnetic species D. lumholtzi as in Nepal and Northern India or only "temperate" Dophnia spp. occur as in Cuba. It appears from the above data that high temperatures limit the occurrence of most Daphnia spp. either directly or indirectly. 


\section{Other Found}

A wide range of invertebrates were collected with the Rotifera, Cladocera and Copepoda. They are listed with the percentage occurrence in each habitat type in Table 3. The sampling methed used is strongly biased towards collecting small animals in the water column and those associated with vegetation. However the large number of samples should give some measure of the ccmmcnness, rarity or absence of certain groups of amimals. Besides fauna in the water column and on vegetation, forms living on the surface of the bottom sediments would be collected.

Only the testacean protozoans could be identified in the preserved samples. Arcella spp. were the commonest while Centropyxis and Difflugia were far less commcn. Hydra, of which two species are known from Sri Lanka, was found occasionally. Rhabdocoeles were quite common in ponds but triclads were not recorded. Triclads are quite rare in tropical freshwaters. The statoblasts of ectoprocts float readily and were often collected. Plumutella repens appears to be much cc mmcrer than Lophobodella carteri from their records in plankton samples. Nematodes were often fcund in the samples where the bottom sediment had been stirred up. Oligochaetes were quite common and like the rematodes, Chironomidae, Chaoborus and Ostracoda they come from the superficial layer of the bottom sediments. Chaoborus is also planktonic. Ostracoda and Chironomidae were the most commonly recorded members of these groups followed by the Oligochaeta and Chaoborus. Oligochaetes were absent in the limnetic samples (lakes - 300 ha.) and Chaoborus was most often found in limnetic samples and rare in shallow habitats. Its occurrence in large reservoirs is only slightly less than the Chironomidae. Mindis (1965) found that Chaoborus (Corethra) had a higher standing crop (numerical) than the Chironomidae in the benthos. Darlington (1977) found the same order of dominance (biomass) of Chaoborus, Chironomidae and Oligochaetes in the benthos of Lake George, Uganda. Ostracoda comprise a mumerous and widely occurring group in benthos. They are oftem ignored or mentioned only in passing because of real or imagined difficulties in diagnosing the mo to species. In the tropical regions Ostracoda are sometimes plank $\mathrm{K}^{+}$nic. They have been recorded in the plankton in Sri Lanka (Apstein 1907); Venezuela (Brehm 1939); Indonesia (Klie 1933, Ruttmer: 1943 and Green et al., 1976) and Africa (Cameroons) by Green et al. (1974). Dr. V. Hruska (personal communication) says that they were common in the plankton of a reservoir in Cuba. Only a few species are known to be planktonic and $\mathbf{M r}$. $\mathbb{R}$. Victor (personal communication) says that the systematics of the Asian planktonic species is confusing. Also planktonic species appear to be "good" benthic species quite often.

The planktonic stages of the parasitic cyclopoid Copepoda were rare and found only in samples: from reservoirs. Four genera are found in Sri Lanka namely Ergasilus, Paraergasilus, Lamprogleano and Lernaea (Fernando and Hanek 1973a, 1973b). Hydracarina were relotively common and appeat in all types of habitats except flowing waters with almost the same degee of frequency. These animals are usually associated with vegetation but seem to be also common in the limmetic region judging from the present records. The remaining fauna were recorded only in a few of the samples. Conchostraca and Anostraca are usually found only in arid areas except for Cyclestheria hislopi which occurs in ricefields and reservoirs. It is according to Junk (1977) typically associated with vegetation. It is surprisingly quite rare in the samples and it was probably discarded because of its large size. Insect larvae and the adults and larvae of Hemiptera and Coleoptera were rare in the samples. However when a large net was used more of these larger fauna were collected by Femando (1965) in a large lake margin.

If we compare these fauna with what would be axpected in a temperate region certain cbvicus differences are seen. There is an absence of triclads in the samples whereas in to m ferete ur gic Is this group would certainly have been recorded. There are also mo Isopoda and Amphipoda in the 
samples. These two groups are not common in the tropics as noted by Beadle (1976). However Caridina (Crustacea : Atyidas) not found in temperate waters occur in all types of habitats.

\section{DISCUSSION AND SUTHMARY}

About 500 samples of freshwater zooplankton collected during 1965-1974 from Sri Lanka were studied in detail. The samples came from all parts of the island, include all types of freshwater habitat and cover all seasons of the year. Seven habitat types were disignated, namely ponds, reservoirs $<300$ and $>300$ ha, ricefields, villus (flood lakes), rivers and streams and miscellaneous habitats (usually smail in extent and man-made). All the Rotifera, Cladocera and Copepoda were enumerated and the results analysed.

The zooplankton consists of a typical tropical assemblage. The Rotifera are characterised by the dominance of the genus Brachionus and Keratella tropica. However, unexpected species like Kellicottia longispina and Keratella earlinge considered temperate species were found. Brachionus donneri endemic to the Indian region was also found. The Cladocera species are fewer in number than in temperate regions and have three distinctly dominant species in the limnetic region, namely Ceriodaphnia comuta, Diaphanosoma excisum and Moina micrura. These species are tropicopclitan and enrytopic occurring in lakes throughout the tropics and often dominating in the limnetic zoroplankton. A few other Cladocera occur fairly commonly in the limnetic region. Tlese are Daphnia Iumhoitzi, Bosminopsis dietersi, Pseudosida bidentata, Chydorus ewrynotus and Chydons barroisi. Daphnia lumholtzi and Bosninopsis dietersi seem to be truly limnetic. Chydorus barroisi and Ch. eurynotus probably occupy the same niche as Chydorus sphaericus which is occasionally found in the limnetic region of temperate lakes.

Two cyclopoid copepods dominate in the limnetic zooplankton. These are the herbivorvous Themocyclops crassus and the carnivorous Mesacyclops leuckarti. Again these are tropicopolitan and occur in limnetic situations where they are the dominant cyclopoics. They are also eurytcpic.

Only one calanoid was at all common, namely Phyllodiaptomus annae, a eurytopic species found in all types of habitats in Sri Lanka.

There are no clear-cut differences between the species compositon of the difierent habitats though ponds, small reservoirs and large reservoirs resemble one another more clcsely tran the ofler habitats. The richest zooplankton fauna seems to be in ponds and small reservoirs.

The limnetic zooplankton of Sri Lanka is typical of the tropical region in species ccupcsition. This has been demonstrated by reference to previcus wcrk from Asia, Africa ard. Scuth America. An attempt has also been made to explain the differences between tropical and terperate region zooplankton. The larger limnetic Cladocera which dominate the plankton in terperate regic ns and belong to the genus Daphnia are rare or absentin the tropics. The uniform high ten peratures prctably reduce species diversity and certainly select for smaller cladocerans. Fecundity is lowered in scme Daphnia spp. by high temperatures $\left(>20^{\circ} \mathrm{C}\right)$. Perhaps this applies to all large Daphnia spp. The uniform high temperatures of the habitats probably is partly responsible for the lack of diversity in the Copepoda too. But there appears to be a reasonably large number of Rotifera, although the number of "good" limnetic species given by Tonolli (1962) for a typical temperate lake has a much higher number than in Sir Lanka reservoirs $>300$ ha. Fish which feed on larger zooplarkters have a smaller size to deal with than in temperate zooplankton. Since invertebrate predators feed on smaller 
zooplankton the size spectrum available to fish and invertebrates may overlap to a considerable degree causing competition to be severe. The elimination of larger zooplanktonic Crustacea in tropical lakes seems to be due largely to temperature effects. Predation by fish may play a subsidiary role.

The small number of typically limnetic zooplankton in tropical lakes is due certainily to the action of many factors including temperature and precator pressure. To this list must be acded the food which is dominated by bluc-green algae in the tropics and also the zocplanktons must he resistant to toxins produced by these algae. The interaction of algae, higher plants, zocplankton predatcrs, zooplankton herbivores and fish predators cause the species compcsiticn to te in a state of dynamic balance. Individual species may show escape behaviour, searching ability, varying medes of predation, change in pigmentation and many other adaptations.

\section{ACKNOWTLOGEMINTS}

This work was possible because of the co-operation extended to me by a number of scientists in different parts of the world. Professor D. G. Frey, Bloomington, Indiana, Dr. N. N. Sminov, U.S.S.R. Academy of Sciences, Moscow and Dr. V. Korinek, Charles University, helped with identifcations andliterature. My conlecting was assisted by Mr. P. P. Karunaratre, National Museum, Colombo, Sri Lanka, and Mr. P. B. Fernando, Nugegoda, Sri Lanka.

\section{REE ERENCES}

ADAMS, F. D.

1929-The geology of Ceylon. Canadian J. Res., $1: 425-511$.

APSTEN, C.

1907-Das plancton in Colorabo See auf Ceylon. Zool. Jb. (A.bt. Syst.), $25: 201-244$.

APSTEN, C.

1910-Das plancton des Gregory See auf Ceylon. Zool. Jb. (Abt. Syst.), $29: 661-680$.

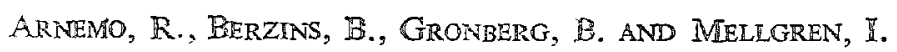

1968-The dispersal in Swedish waters of Rellicottia bostoniensis (Rousselet) (Rotatoria). Oikos, $19: 351-358$. A.RORA, G. L. $1: 52-100$

1931- Tauna of Lahore 2. Entomostraca (Water fleas) of Lahore. Bitl. Dept. Zool. Pulmab University, BÄR, G.

1924-Uber Cladoceren von der Insel Ceylon. Jena Z. Naturw., 60;83-126.

BAUDOUIN, M. F. AND SCOPPA, P.

1977-Acute toxicity of various metals to freshwater zooplankton. In Bullatin of Environmental Contamination and Toxicology No. 12 : pp. 745-751. Springer Verlag, N.Y.

BEADLE, $\mathbb{H}$. C. 1974-The inland waters of tropical Africa. Longmans, Lond., 365 pp.

BeLL, R. I. AND WARD, $\mathbb{E}$. J.

1970-Incorporation of organic carbon by Daplunia pulex, Limnol. Oceanogr., 15:713-726.

BISWAS, S.

1966-Five species of Daphniidae (Crustacea) from Simia hills in India, with a new record of Alona costata Sars from IKameng Division, Nefa. J. Zool. Soc. India, 16:90-98.

BISWAS; S.

1971-Fauna of Rajasthan, India Part II Crustacea : Cladocera. Rec. Zool. Survey India, 63:95-141. BLACHE, J.

1959-Apercu sur le plancton des eaux douces du Cambodge. CYMIUM, $6: 62-94$. 
BRADY, G. S.

1886-Notes on Entomostraca collected by Mr. A. Haly in Ceylon. J. Linn. Soc. Lond. (Zool.), 10:293-317.

BRANDL, Z. AND FERNANDO, C. $\mathrm{H}$.

1974-Feeding of the copepod Acanthocyclops vernalis on the cladoceran Ceriodaphnia reticulata under laboratory

conditions. Can. J. Zool., $52: 99-105$.

BRANDL, Z. AND FERNANDO, C. $H$.

1975a-Food consumption and utilization in two freshwater cyclopoid copepods (Mesocyclops edax and Cyclops viciniss). Int. Rev. ges. Hydrobiol., $60: 471-494$.

BRANDI, Z. AND FERNANDO, C. $\mathrm{H}$. $2959-2965$.

1975b-Investigations on the feeding of camivorous cyclopoids. Verh. Internet. Verein. Limnol., 19:

BRANDL, ZZ. AND FERNANDO, C. $\mathbb{H}$.

Iimnol., 20 .

1978-Prey selection of the cyclopoid copepods Mesocyclops edax and Cyclops vicinus. Werh. Internat. Verein.

BRANDLOVA, J., BRANDL, Z. AND FERNANDO, C. $\mathrm{H}$.

1972-The Cladocera of Ontario with remarks on some species and distribution. Can. J. Zool., 50:1373-1403.

BRANDORFF, G. O.

1977-Untersuchumgen zur populations-dynamik des Crustacean planktons im Lago Castanho (Amazonas,

Brazilien). Dissertatun Christian-Albrechts Unwersität zu Kiel. $108 \mathrm{pp}$.

BREHM, V.

1933-Die cladoceren de Deutschen Limnologischen Sunda-Expedition. Arch. Hydrobiol., Suppl.11:631-771.

BREHM, $V$.

1939-La Fauna maicroscopica del Lago Péten, Guatemala. An. Esc. nac. Cien. biol. Mex. 1:173-202.

BRINCK, P., ANDERSSON, $\mathbb{H}$. AND CEDERHOLM, $\mathbb{L}$.

1971-Report No. I from the Lund University Ceylon Expedition in 1962. Ent. Scand. Suppl. $1: 3-36$.

BROOK, A. J. AND RZOSKA, J.

1954-The influence of the Gebel Aulyia dam on the development of Nile plankton. J. Anim. Ebol.,23:101-114.

PROOKS, J. $\mathbb{L}$.

1957-The systematics of North American Daphnia. Mem. Conn. Acad. Arts. Sci., $13: 1-180$.

Broors, I. I.

1963-Cladocera Ln Freshwater Brology. Edited by W. T. Edmondson, pp. 587-656. John Wiley, New York.

BROOKS, I. I.

1968-The effects of prey size selection by lake plantctivores. Syst. Zool., $17: 272-291$.

BRoOKS, J. I. AND DODSON, S. I.

1965-Predation, body size and composition of plankton. Science, $150: 28-35$.

BURGIS, M.

1970-The effects of temperature on the development time of eggs of Thermocyclops sp., a tropical cyclopoid copepod from Lake George, Uganda. Lt.nnol. Oceanogr., $15: 742-747$.

BURGIS, M.

1971-The ecology of production of copepods, paricularly Thermocyclops hyalinus, in the tropical Lake George,

Uganda, Freshw. Biol., $1: 169-192$.

BURGIS, M. I.

1974-Revised estimates for the bionass and production in Iake George, Uganda. Freshw Biol., $4: 535-541$.

BURGIS, M. I. AND WAIKER, A. IF.

1972-A preliminary comparison of the zooplankton in a tropical and a temperate lake (Lake George, Uganda

and Lock Leven, Scotiand). Verh. Interinant. Verein. Linnol., $18: 647-655$. 
Burgis, M. I., Darlington, J. P. E. C., Dunn, I. G., Ganf, G. C., Gwohaba, J. J. and MicGowen, L. M. $271-298$.

1973-The biomass and distribution of organisms in Iake George, Uganda. Proc. R. Soc. Lond., (B), 184:

BURNS, C. W. AND RIGLER, F. H.

1967-Comparison of filtering rates of Daphinia rosea in lake water and in suspensions of yeast. Limnol. Oceanogr., $12: 492-502$.

Chengalath, $\mathbb{R}$. AND Fernando, C. $\mathbb{H}$.

1973-Rotifera from Sri Lanka (Ceylon). 1. The genus Lecane including the desciption of two new species. Bull. Fish. Res. Stn. Sri Lanka (Ceylon), 24 :13-27.

Chengalath, R., Fernaindo, C. H. and George, M. G.

1972-The planktonic Rotifera of Ontario with keys to genera and species. Univ. Waterloo Eiol. Ser., No. 2 $1-40$.

Chengalath, R., Fernando, C. H. and Koste, W.

1973-Rotifera of Sri Lanka. 2. Further studies on the Eurotatoria including new. records. Bizhl. Fish. Res.

Stn. Sri Lanka (Ceylon), $24: 29-62$.

Chiengaitath, R., Fernando, C. H. and Koste, W.

1975-The Rotifera of Sti Lanka. 3. Dascriptions of new species and gew records with a list of species in Sri

Lanka and discussion of distribution. Bull. Fish. Res. Stzr. Sri Lanka (Ceylon), 25 : 83-96.

Clarke, N. V.

1978-A comparison of the zooplankton of Lake $\mathbb{K}$ - Ainji and the rivers Niger and Swashi. Hydrobiologia, $58: 17-23$.

COORAY, P. G.

1967-An Introduction to the geology of Ceylon. Spolia Zeylai, $31: 1-324$.

COSTA, H. H. AND DE Silva, S. S.

1959-Hydrobiology of Colombo (Beira) lake. 1. Diurnal variations in temperature, hydrochemical factors and zooplankton. Bull. Fish. Res. Str. Ceylon, $20: 141-149$.

COSTA, H. H. AND STARMUhluner, $\mathbb{F}$.

1972--Results of the Austrian-Ceylonese hydrobiological mission 1970 of the 1 st Zoological Institute of the

University of Vienna (Austria) and the Department of Zoology of the Vidyalankara University of Ceylon, Kelaniya.

Bull. Fish. Res. Strh. Sri Lanka (Ceylon), $23: 43-76$.

DADAY, $\mathbb{E}$.

1898a-Microscopische Susswasserthiere aus Ceylon. Termeszetr. Fuz. (Budapest), $21: 1-123$.

DADAY, E.

$1898 b$-Freshwater microscopical animals from Ceylon (In Hungarian). Mathematikai es Termezettodomany Ertestito, Budapest, $16: 89-100$.

Darlivgton, J. P. E. C.

1977-Temporal and spatial variation in the benthic invertebrate fauna of Lake George, Uganda. J.Zool. Lond., $181: 95-111$.

Edmondson, W. T.

1965-Reproductive rate of planktonic rotifers as related to food ans temperature in nature. Ecol. Monogr., $35: 61-112$.

Fernando, C. H.

1965-A preliminary survey of 21 Ceylon Lakes. 3. Parasites and predators, food of fish and marginal fauna. Bull. Fish. Res. Stn. Ceylon, $18: 17-27$.

FerNando, C. H.

1971-The role of introdiced fish in fish production in Ceylon's freshwaters. In The Scientific management of animal and plant communities for conservation. Edited by E. Duffey and A. S. Watt, pp. 295-310. Blackwells; Oxford.

Fernando, C. $H$.

1973-Man-made lakes of Ceylon: A biological resource. In Man-made Lakes: Their problems and environmental effects. Edited by W. C. Ackermann, Gilbert F. White and E. B. Worthington, American Geophysical Union Monograph, $17: 664-671$, Washington, D. C.

$4-\mathrm{A} 45286(80 / 03)$ 
FERNANDO, C. $\mathbb{H}$.

1974-A gufde to the freshwater fauna of Sri Lanka (Ceylon). Supplement 4. Bull. Fish. Res. Str. Sri Ianka (Ceylon), $25: 27-81$.

FERNANDO, C. H.

1977-Investigations on the aquatic fauna of tropical ricefields with special reference to South-East Asia. GEO-ECO-TROP, $\mathbb{1}: 169-188$.

FERNANDO, C. $\mathbb{H}$.

1978-The freshwater invertebrate fauna of Sri Lanka. Colombo Ruseurn Centenary Volume. Spolia Zeylam.. $35:$

FERANANDO, C. H.

1979-Lake and Roservoir Ecosystems in South-East Asian (Oriental Region). In Lake and Reservoir Ecosystenss Zdit. Frieda B. Taub, Elsivier, North Holland Publishers, Amsterdam.

FERNANDO, C. H. AND EILEPOLA, W. B.

1969-A preliminary study of two viliage tanks (reservoirs) in the Polonnaruwa area with biological notes on these reservoirs in Ceylon. Bull. Fish. Res. Sttr. Ceylon, $20: 3-13$.

FERNANDO, C. H. AND HANER, G. 1973a-Some parasitic Copepoda fron Sri Lanka (Ceylon) with a synopsis of parasitic Crustacea fron Ceylonese freshwater fishes. Bull. Fish. Res. Str. Sri Lanka (Ceylon), 24:63-67.

FERNANDO, C. H. AND HANEK, G.

1973b- Two new species of the genus Ergasilus Nordmann (Copepoda, Ergasilida) from Ceylon. Crustaceane $25: 13-20$.

FERNANDO, C. H. AND HANEK, G.

1976-A new genus of calanoid copepod from Sri Lanka (Ceylon). Crustaceana, 30:82-88.

FERNANDO, C. $\mathbb{H}$. AND INDRASENA, H. H. A.

1969-The freshwater fisheries of Ceylon. Rull. Fish. Res. Stro. Ceylon, $20: 101-13 \%$.

FRRY, D. G.

1969-A limnological reconnaissance of Lake Lanao. Verh. Internat. Verein. Limnol., $17: 1090-1102$.

Galbraith, M. G.

1967-Size selective predation of Daphnia by rainbow trout and yellow perch. Trans. Amerc. Fish. Soc.,96:1-10.

GALBRATTH, M. G.

1975- The use of large Daphnia as indices of fishing quality for rainbow trout lakes. Verh. Internat Verein.

Limnol., $19: 2485-2492$.

GETSLER, $R$. $559-572$.

1967-Limznologische-Ichthylogische beobactungen in Sudwest-Ceylon. Int. Rev. ges. Hydrobiol., 52:

GILBERT, J. AND WAAGE, J. KK.

1967-Asplanchna, Asplanchna-substance, and postero-lateral spine length variation of the rotifer Brachionus calyciflorus in a matural environment. Ecology, 48:1027-1031.

GOULDEN, C. E.

1968-The systematics and evolution of the Moinidae. Trans. Amer. Phil. Soc. Philadelphia, $58: 1-101$.

GRERN, J.

1962-Zooplankton of the river Sokoto. The Crustacea. Proc. Zool. Soc. Lond., 138:415-453.

GreEN, $J$.

1967-The distribution and variation of Daphnia luminoltzi (Crustacea : Cladocera) in relation to fish predation in Lake Albert, East Africa. J. Zool. Lond., $151: 181-197$.

Greet, J.

1971-Latitudinal variation in associations of planktonic Rotifera. J. Zool. Lord., 167 : 31-39.

Green, J., Corbet, S. A., Watts. (Nefe Betney) and Oey Biauw lan

1976-Ecological studies on Indonesian lakes. Overturn and resiratification of Ranau Iamongen. $J . Z o o l$. Soc. Loncd, $180: 315-354$. 
Grabr, \$., CORBET, S. A. AND BeTNEY, E.

1974-Ecological studies on crater lakes in West Cameroon. Debundsha Iake. J. Zool. Soc. Lond., 173: 199-223.

GUTREY, $\mathbb{R}$.

1906-On two Entomostraca from Ceylon. Spolia Zeylan., 4:126-134.

GURNBY, $\mathbb{R}$.

1916- On some freshwater Entomostraca from Ceylon. Proc. Zool. Soc. Lond. (1916) 33-343.

GURNIF: $\mathbb{R}$.

1931-A species of freshwater copepod Paradiaptomus greeni (Guraey) common to South Africa, Ceylori and India. Zool. Anz., $92: 301-303$.

HACL, D. J.

1964 - An experimental approach to the dynamics of a natural population of Dophoia galeata merdorae. Ecologss, $45: 94-112$.

MALE, D. I., COOPER, W. E. AND WERNER, E. E.

1970-An experimental approach to the production dynamics and structure of freshwater animal communities.

Limpol. Oceanogr., $15: 839-929$.

HALL, D. J., THREKELD, S. T., BURN, C. W. AND CROWLEY, P. H.

1976-The size eficiency hypothesis and the size structure of zooplankton communities. Anz?. Rev. Ecol. Syst. $7: 177-208$.

IHANEY, J. F.

1973-An in situ examination of the grazing activities of natural zooplankton communities. Arch. Hydrobiol. $72: 87-132$.

HASLER, A. D. AND JONES, E. $359-364$.

1949-Demonstrations of the anfagonistic action of large aquatic plants and algae on rotifers. Ecology, 30:

HAUER, J.

1938-Die Rotatoriem von Sumatra, Java and Mali. Arch. Hydrobiol, Suppl. 15 : 297-602.

MPRBACEK, $\mathbb{I}$.

1962-Species composition and the amount of zooplankton in relation to fish stock. Razpr. Cesk. Akad. Feas.

Rada Prir. Ved., $72: 1-116$.

HEU: KA, $V$.

1977-(Personal communication).

IVLEY, Y.S.

1937-Experimental ecology of the feeding of fishes. Transl. from Russian by Douglas Scott, Yale Universiry Press, New Haven, U.S.A. 302 pp.

JACCARD, $\mathbb{P}$.

1908-Nouvelles recherches sur la distribution fiorale. Soc. Vaud. Sci. Nat. Bull., 44:223-270.

MUNK, W.

1977-The invertebrate fauna of the flowting vegetation of Bung Borapet, a reservoir in Central Thailand. Hydrobiologia, 53 : 229-238.

KIERER, $F$. 1933-Die focilibenden copepoden der Binnenge wasser von Insulinde. Arch. Hydrobiol. Suppl., 12:519-625.

$\mathbb{K L I E}, W$.

1933-Die Ostracoden der Deutschen Limnolgischen Sunda-Expedition. Arch. Hydrobiol. Suppl., 11:447-502. KORINEK, $V$. 1976-(Personal communication).

KUMAE, A. S.

1974-Distribution of macrofauna in a Malayan Mangrove shore. J. Anim. Ecol., $43: 51-69$.

LAI, H. C. AND ChUA, T. E.

1976 -Limnological features of the Muda and Pedu reservoirs with an observation on their suitability for fisil culture. Malaysian Agric. J., 50 : 480-501. 
IEFEVRE, M.

1950-Aphanizomenon gracile Iemm., Cyanophyte defavourable au zooplankton. Ann. Sta. Cent. Fydrobiol. Appl., $3: 205-208$.

IESEUR, B. W.

1960-The life history of Daphnia pulex spp. pulicoides. Proc. Mont. Acod. Sci., $19: 80-83$.

LEWIS, W. M. 1974-Primary production in the plankton community of a tropical lake. Ecol. Monogr., 44: 377-409.

LYNCH, $\mathbb{M}$.

1977-Fitness and optimal body size in zooplankton populations. Ecology, $58: 763-774$.

MamariL, A. C. 1977-Freshwater zooplankton of the Philippines (Rotifera, Cladocera and Copepoda). M.Sc. Thesis, University of Waterloo, Canada. $151 \mathrm{pp}$.

MCARTHUR, $\mathbb{R}$. 1960-On the relative abundance of species. Amer. Nat., 94:25-36.

MENDIS, A. S. 1964-A contribution to the limnology of Colombo Lake. Bull. Fish. Res. Stn. Ceylon, $17: 213-220$.

MENDIS, A. S.

1965-A preliminary survey of 21 Ceylon lakes, 2. Limnology and food production potential. Bull. Fish. Res. Stm. Ceylon, $18: 7-16$.

MENDIS, A. S.

1976-Country Report, Sri Lanka. In Symposium on development and utilization of inland fishery resources. ndo-Pacific Fisheries Council meetings, Colombo, Sri Lanka, October 1976. 24 pp. and 24 pp. Appendix.

INendis, A. S. And Fernando, C. $\mathrm{H}$. 1962-A guide to the freshwater fauna of Ceylon. Bull. Fish. Res. Stn. Ceylon, 12:1-160.

MIIZUNO, T. AND MIORI, S. 1970-Preliminary hydrobiological survey of some South-east Asian inland waters. Biol. J. Limn. Soc., 2 : 77-117. Monaḱv, A. V. 1972-Review of studies on feeding of aquatic invertebrates conducted at the Institute of the Biology of Inland Waters, Academy of Sciences, U.S.S.R. J. Fish. Res. Bd. Canada, $29: 363-383$.

Monakov, A. V. $1976-N u t r i t i o n$ and trophic relations of freshwat er Copepoda (in Russian). Nauka, Leningrad, 170 pp.

Moriarty, D. I. W., Darimaton, J. P. E. C., Dunn, I. G., Mortarty, M. and Tevlin, M. P. 1973-Feeding and grazing in Lake George, Uganda. Proc. R. Soc. Lond. (B), $184: 299-319$.

NAUWERCK, A. 1959-Bestimmung der filtreirrate limnischer Planctontiere. Arch. Hydrobiol. Suppl., 25 : 83-101.

PESLER, B. 1977-On the global distribution of the family Brachionidae (Rotatoria). Arch. Hydrobiol. Suppl., 53 : 225-306. PENNAK, R. W. 1957-Species composition of limnetic zooplankton communities. Limnol. Oceanogr., $2: 222-232$.

POPPE, S. A. AND MiRazeK, S. 1895-Die von Herrn Dr. H. Driesch auf Ceylon gesammeltem Susswassen Entomostraken. Breh. Jabs. Hamb. Wiss. Anst., $12: 139-142$.

PROSZYSNKA, M. 1963-On the problem of differentiating Cladocera and Copepoda fauna in ponds and small water bodies in the light of present faunistic literature. Polsk. Arch. Hydrobiol., $11: 77-96$.

PROSZYNSKA, M. 1968-Bibliography of Cladocera and Copepoda of African Inland Waters. Ghana J. Sci., $7: 37-49$. 
Reerss, $F$.

1977-The benthic zoocoenoses of Central Amazon Varzea lakes and their adaptations to annual water level fictuations. GEO-ECO-TROP., $1: 65-75$.

$\mathbb{R} U T T N E R, \mathbb{F}$.

1943-Beobactungen uber die tagliche Vertikalwanderung des planctons in tropischen seen. Arch. Hydrobiol. Suppl., $40: 474-492$.

RUTTNER, $\mathbb{F}$. $242 \mathrm{pp}$.

1952a-Fundamentals of Limnology. English Transl. by D. G. Frey and F. E. J. Frey, Univ. Toronto Press.

SinRorA, A.

1952b-Planktonstudien der Deutschen Limnologische Sunda Expedition. Arch. Hydrobiol Suppl., $21: 1-274$.

RzOSKA, J.

1956-On the variability and status of the cladoceran Ceriodaphnia cornuta and Ceriodaphnia rigaudi. Ann. Mag. Nat. Hist. (12), $9: 505-510$.

Scourfield, D. J. AND HaRding, J. P.

1966-A key to the British species of freshwater Cladocera. Freshwater Biol. Assn. Scient. Publn. $5: 55$ pp.

SEYMOUR-SWEWLI., R. B. S. S.

1934-A study of the fauna of the Salt lakes, Calcutta. Rec. Indian Mus., $36: 45-121$.

SETROTA, A.

1963-The plankton of south Vietinam. Freshwater zooplankton. Overseas Technical Co-operation Agency. Jepan No. $13: 1-145$, Tokyo.

SIRTMANNE, C. H. L.

1953-A survey of the potable and industrial waters in Ceylon. Proc. Ceylon Assn. Adv. Sci. (1952), 5-36.

SaITH, K. E. AND FERNANDO, C. H.

1978-A guide to the freshwater calanoid asd cyclopoid copepoda Crustacea of Ontario. U;iv. Waterloo Biol. Ser.: $18: 1-74$.

SNEATHY, P. H. A. AND SOKAL, R. R.

1973-Numerical Taronomy. W. H. Freersan, San Francisco. 573 pp.

TONOLI, $\mathrm{V}$. $81-134$

1962-L'attuale Situazione del popolamento planctonico del Lago Maggiore. Mem. Its. Fal. Idrobiol., is :

VICTOR, $\mathbb{R}$.

1977-(Personal communication).

WEERAKOON, A. C. J.

1957-Some animals of the paddyfield. Loris (Ceylon), $7: 1-8$.

WELLS, I. $\mathbb{R}$. $556-565$.

1970-Effects of alewife predation on zooplankton populations in Lake Michigan. Limnol. Oceanogr. 15:

WeNINGER, G.

1972-Hydrochemical studies on mountain rivers in Ceylon. Bull. Fish. Res. Sth. Sri Lanka (Ceylon), 23:77-100.

ZARET, T. M.

1969-Predator balanced polymorphism of Ceriodaphnia cornuta Sars. Limnol. Oceanogr., 14 : $301-333$.

ZARET, T. M. $171-184$.

1972a-Predators, invisible prey and the nature of polymorphism in the Cladocera. Limmol. Oceanogr., 17 :

ZARET, T. M.

$1972 k$-Predator-prey interaction in a tropical lacustrine ecosystem. Ecology, $53: 248-257$.

ZARET, T. M.

1975-Strategies for existence of zooplankton prey in homogeneous environments. Verh. Internat. Verein. Limnol., $19: 1484-1489$. 
TAPILE I

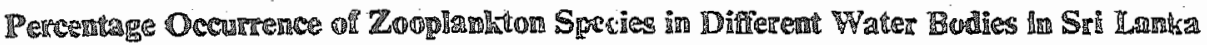

\begin{tabular}{|c|c|c|c|c|c|c|c|c|}
\hline & Habilâ & 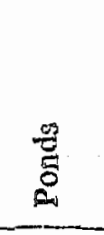 & 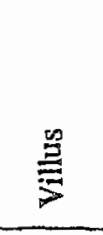 & 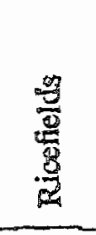 & 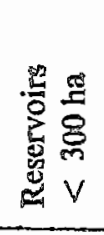 & 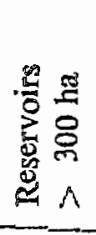 & 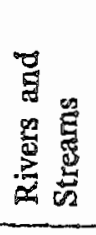 & 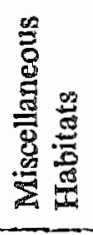 \\
\hline \multicolumn{2}{|l|}{ Number of Somples } & 85 & 10 & 54 & 159 & 98 & 24 & 43 \\
\hline \multicolumn{9}{|l|}{ \$pecies } \\
\hline ROtilerat: & $\cdots$ & 2.35 & 10.00 & & 4.40 & 7.14 & 4.17 & 232 \\
\hline *A. Gasa (Gosse) & $\ldots$ & 20.00 & & 3.70 & 14.47 & 12.24 & 8.33 & 16.28 \\
\hline - Asplanchna brightwelli Gosse & .. & 5.88 & 10.00 & 7.41 & 27.04 & 29.59 & & 9.30 \\
\hline A. priodonia Gosse & .. & 2.35 & & 1.85 & 1.89 & 2.04 & & \\
\hline A. sieboldi (Leydig) & . & 1.18 & & 1.85 & 1.89 & 2.04 & & \\
\hline Asplanchnopus multiceps (Schrank) & .. & 12.94 & 10.00 & 16.67 & 6.92 & & & 9.30 \\
\hline$*$ Brachionus angularis Gosse & .. & 9.41 & & 7.41 & 22.01 & 33.68 & 16.67 & 6.98 \\
\hline B. bidentata Anderson $\ldots$ & .. & 1.18 & & & 1.89 & & & 4.65 \\
\hline \#B. budapestensis Daday ... & .. & & & & 0.63 & 1.02 & & \\
\hline **B. calycifiorus $\mathbb{P a l l a s}$ & .. & 9.41 & 10.00 & 9.26 & 27.67 & 51.02 & 4.17 & 16.28 \\
\hline$\approx \mathbb{B}_{\text {. caudatus Hauer }}$ & . & 9.41 & & 2.83 & 14.47 & 25.51 & 12.50 & 2.32 \\
\hline B. donneri Brehm & .. & & & & 1.89 & 1.02 & & \\
\hline B. falleatus Zacharias & .. & 9.41 & & 5.56 & 38.36 & 69.39 & 16.67 & 4.65 \\
\hline$* *$ B. forficula Wierzejski $\quad$. & . & 3.53 & 10.00 & 7.41 & 26.41 & 71.43 & 8.33 & 6.98 \\
\hline B. leydigi Cohn & $\therefore$ & & & & 2.52 & 1.02 & & 4.65 \\
\hline B. dilsoni Ahlstrom & . & & 10.00 & & 2.52 & 5.10 & & \\
\hline$\Rightarrow$ B. patuius Muller & .. & 34.12 & 40.00 & 27.78 & 10.69 & 6.12 & 8.33 & 30.23 \\
\hline D. plicatilis Muller & . & 1.18 & & & & & & 2.32 \\
\hline$\because \mathbb{B}_{0}$ quadridentatus Hermanin & . & 15.29 & 30.00 & 20.37 & 16.98 & 16.33 & 8.33 & 18.60 \\
\hline$*$ B. rubens Ehrenberg .. & . & 4.71 & & 3.70 & 7.55 & 6.12 & $8.3 \hat{3}$ & 2.32 \\
\hline \#B. sessilis Varga & .. & & & & 0.63 & 1.02 & & \\
\hline$* \neq \mathbb{B}_{0}$ urceus $(\mathrm{L})$. & .. & 7.06 & & 1.85 & 7.55 & 5.10 & 8.33 & 4.65 \\
\hline B. urceolaris Muller & .. & 2.35 & & & 3.77 & 4.08 & & \\
\hline Cephalodella forficula Ehrenberg & .. & 1.18 & & 1.85 & 0.63 & & & \\
\hline C. gibba Ehrenberg & . & 2.35 & & & 1.89 & 2.04 & & \\
\hline Collotheca ornata & . & 2.35 & & 3.70 & 2.52 & 8.16 & & 2.32 \\
\hline Colurella sp. Tschugunofï & . & & & & & 8.33 & 2.32 & \\
\hline Conochilus unicomis Rousselet & . & 7.00 & & 14.67 & 2.32 & 3.06 & & 9.30 \\
\hline $\begin{array}{l}\text { Conochiloides dossuarius (Hudson) } \\
\text { C natans (Seligo) }\end{array}$ & & 1.18 & & 1.85 & & 3.06 & & 2.32 \\
\hline${ }^{*}$ C. matans (Seligo) & & & & & & 1.02 & & \\
\hline * Dicranophorus robustus Harring and Mye & & 12.94 & 10.00 & 3.70 & $\begin{array}{r}11.32 \\
2.52\end{array}$ & 2.04 & 4.17 & 2.32 \\
\hline $\begin{array}{l}* \text { Diphenchlanis macrodactyla Hauer } \\
* * \text { D. propatula (Gosse) .. }\end{array}$ & & $\begin{array}{r}3.53 \\
11.76\end{array}$ & $\begin{array}{l}10.00 \\
20.00\end{array}$ & $\begin{array}{l}3.70 \\
9.26\end{array}$ & $\begin{array}{l}2.52 \\
3.77\end{array}$ & $\begin{array}{l}2.04 \\
1.02\end{array}$ & 8.33 & 6.98 \\
\hline $\begin{array}{l}* \mathbb{D} \text {. propatula (Gosse) } \\
\text { Epiphanes macroura (Ba }\end{array}$ & . & $\begin{array}{l}11.76 \\
1.18\end{array}$ & $20.0 \%$ & $\begin{array}{l}9.26 \\
1.85\end{array}$ & 1.26 & 13.26 & 8.33 & 9.50 \\
\hline * * Euphanis dilatata Ehrenberg & & 37.55 & 40.00 & 48.15 & 32.70 & 1.02 & 25.00 & 44.19 \\
\hline $\mathbb{E}$. incisa Carlin & . & 1.18 & & 5.56 & 0.63 & 3.06 & & 4.65 \\
\hline
\end{tabular}

Vallues beiow 0.5 are not included.

*Rare $=<2 \%$ (Total occurrence).

**Eurytopic $=$ occur in at least six of the seven habitat types.

$X=$ previous records orily, not recorded in present study. 
TABRE 1 (Conse)

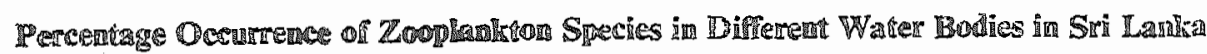

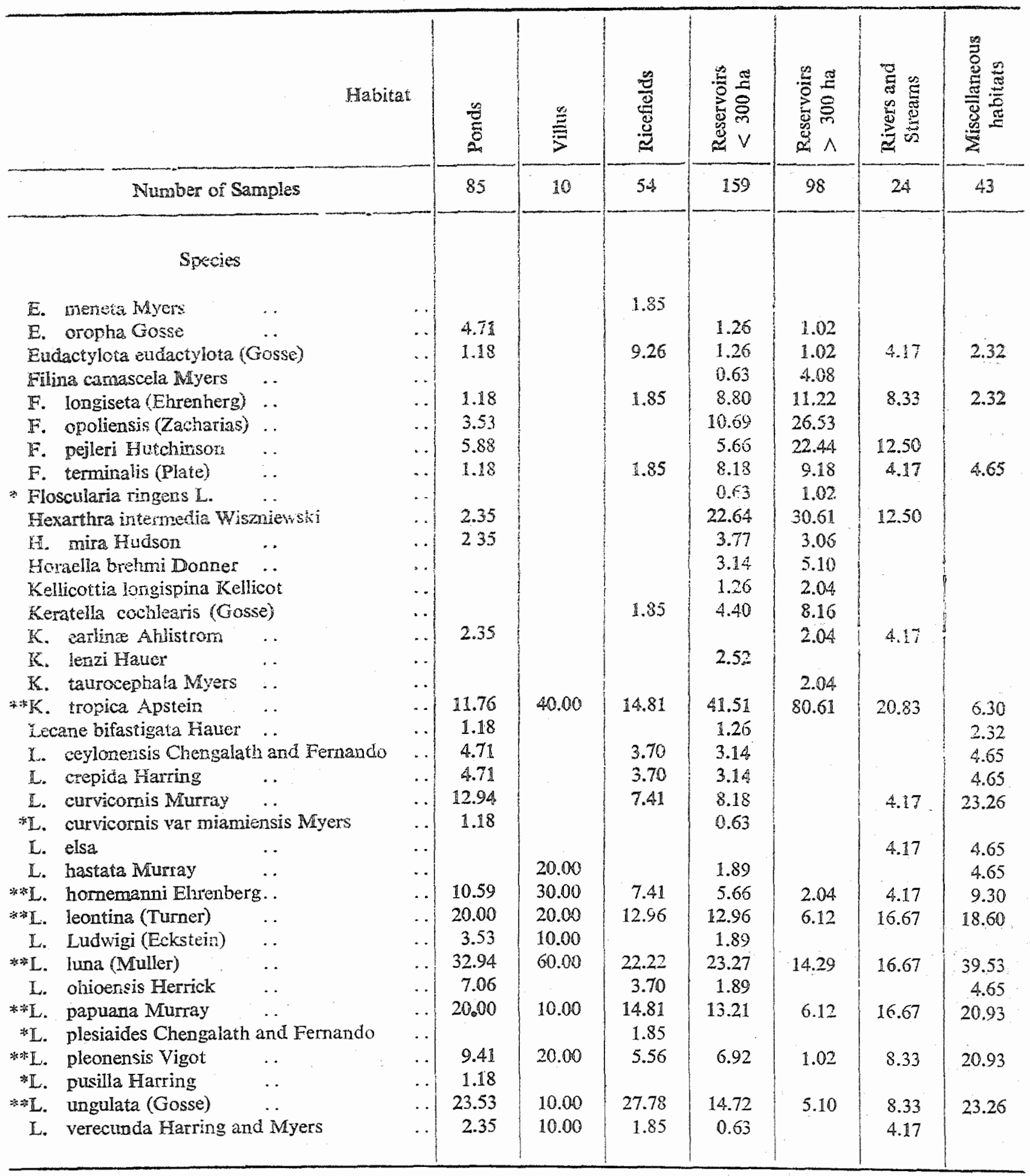

Values below 0.5 are not included.

$* \mathbb{R}$ are $=<2 \%$ (Total occurrence).

**:Eurytopic $=$ occur in at least six of the seven habitat types.

$\mathrm{X}=$ previous records only, not recorded in present study. 
TABLE 1-(Conta)

Percentage Occurremre of Zooplatiliton Stecies in Dišremt Water Rodies in Sri Lanka

\begin{tabular}{|c|c|c|c|c|c|c|c|c|}
\hline Hab & & : & 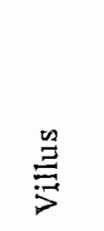 & 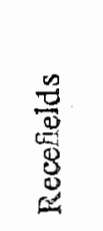 & 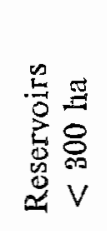 & 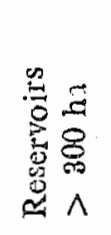 & 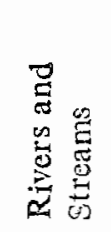 & 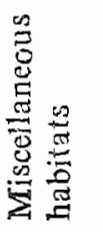 \\
\hline \multicolumn{2}{|c|}{ Number of Samples } & 85 & 10 & 54 & 159 & 98 & 24 & 43 \\
\hline \multicolumn{2}{|l|}{ Species } & & & & & & & \\
\hline $\begin{array}{l}\text { L. sympoda Hauer } \\
\text { *I. syrgenes Haucr }\end{array}$ & $\begin{array}{l}. . \\
. .\end{array}$ & $\begin{array}{l}5.88 \\
1.18\end{array}$ & & 1.85 & & & & 11.63 \\
\hline * *L. bulia (Gosse) & . & 50.59 & 60.00 & 42.59 & 44.65 & 40.82 & 58.33 & 58.14 \\
\hline *L. closterocerca (Schmarda) & .. & 7.05 & 10.00 & & 6.92 & 1.02 & 12.50 & 4.65 \\
\hline *FI. decipiers (Murray) & . & 9.41 & 10.00 & 1.85 & 4.40 & 2.04 & 4.17 & 6.93 \\
\hline toted. elachis Harring and Myers & .. & 4.71 & 10.00 & 7.41 & 1.26 & 1.02 & & 13.63 \\
\hline 1. furcata Murray & .. & 1.18 & & 3.70 & & & & \\
\hline L. hastata (Murray) & .. & 1.18 & & & & & & \\
\hline **L. lunaris (Ehrenberg) .. & $\because$ & 16.47 & 30.00 & 7.41 & 9.43 & 9.18 & 4.17 & 13.95 \\
\hline *I. lanka Chengalath and Fernando & .. & & & 1.85 & & & & \\
\hline L. obtusa (Murray) & .. & 1.18 & & & 1.89 & 3.06 & & \\
\hline I. pyriformis (Daday) & .. & 5.88 & & & 1.89 & & & 6.98 \\
\hline 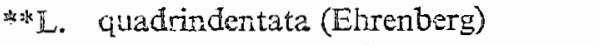 & .. & 8.24 & 20.60 & 7.41 & 6.29 & & 12.50 & 13.95 \\
\hline I. stenroosi (Meissner) $\quad$.. & .. & & & 3.70 & 3.14 & 2.04 & & 2.32 \\
\hline$* * \mathbb{L}$. unquitata Fadeew & .. & 12.94 & 40.00 & 11.11 & 13.21 & 5.10 & 12.50 & 32.56 \\
\hline Iepadella costata Wilfert & .. & 1.18 & & & & & & 2.32 \\
\hline **ipedella ovalis (Muller) & .. & 8.24 & & 1.85 & 1.89 & 1.02 & 8.33 & 6.98 \\
\hline * Lepadella patella (Muller) & .. & 9.41 & 20.00 & 1.85 & 1.89 & 1.02 & 4.17 & 6.98 \\
\hline Iepadella nomboides (Gosse) & .. & 4.71 & & & 0.63 & 1.02 & & 2.32 \\
\hline 虹epadeila triba Myers & .. & & & 1.85 & & & & \\
\hline Macrochaetus collinsi (Gosse) & .. & 2.35 & 1.85 & 1.26 & 1.02 & & & \\
\hline M: sericus (Thorpe) & . & 2.35 & & 3.70 & 1.89 & 1.02 & & \\
\hline Monommata sp. & .. & 2.35 & & & 1.26 & 1.02 & & 2.32 \\
\hline Mytilina acanthophora Hauer & .. & & & & & & 8.33 & \\
\hline II. bisulcata (Lucks) & .. & 3.53 & & & 1.26 & & & \\
\hline M. mucronata (Muller) .. & .. & 1.18 & & & 2.52 & 1.02 & & \\
\hline$*$ *M. ventralis (Ehrenberg) $\quad \ldots$ & .. & 17.65 & 20.00 & 7.41 & 6.92 & 5.10 & 4.17 & 13.95 \\
\hline Notomnata sp. & .. & $3.53^{\circ}$ & & 5.56 & 1.89 & 2.04 & & 4.65 \\
\hline * $*$ Platyias quadricomis Ehrenberg & . & 35.29 & & 29.63 & 13.84 & 10.20 & 25.00 & 13.95 \\
\hline *:Polyarthra đolichoptera Idelson & . & 10.59 & & 3.70 & 7.55 & 5.10 & 4.17 & 9.30 \\
\hline$* * \mathbb{P}$. vulgaris Carlin & .. & 8.24 & 20.00 & 1.85 & 16.35 & 20.411 & 16.67 & 4.65 \\
\hline * Pompholyx complanata Gosse & .. & 25.88 & 10.00 & 12.96 & 27.04 & 33.67 & 37.50 & 34.88 \\
\hline Scariđium iongicaudum Muller & .. & 2.35 & & 1.85 & 0.63 & & & 2.32 \\
\hline Sinantherina semibullata (Thorne) & .. & 5.83 & & 5.56 & 1.89 & 1.02 & & 2.32 \\
\hline S. spinosa (Thorpe) & .. & 4.71 & & 20.37 & 1.26 & 1.02 & & 2.32 \\
\hline *Stephanocerus fimbriatus Goldfuss & .. & & & & 1.26 & & & \\
\hline *Squatinella sp. & .. & & & & 1.26 & & & \\
\hline
\end{tabular}

Values below 0.5 are not included.

W Rare $=<2 \%$ (Total occurrence).

* *Eurytopic = occur in at least six of the seven habitat types.

$X=$ previous records only, not recorded in present study. 
I. B BSE I-(Conid.)

Percentage Occurtence of Zoondaghan Sfecies in Different water Rodfes in Sri Lamia

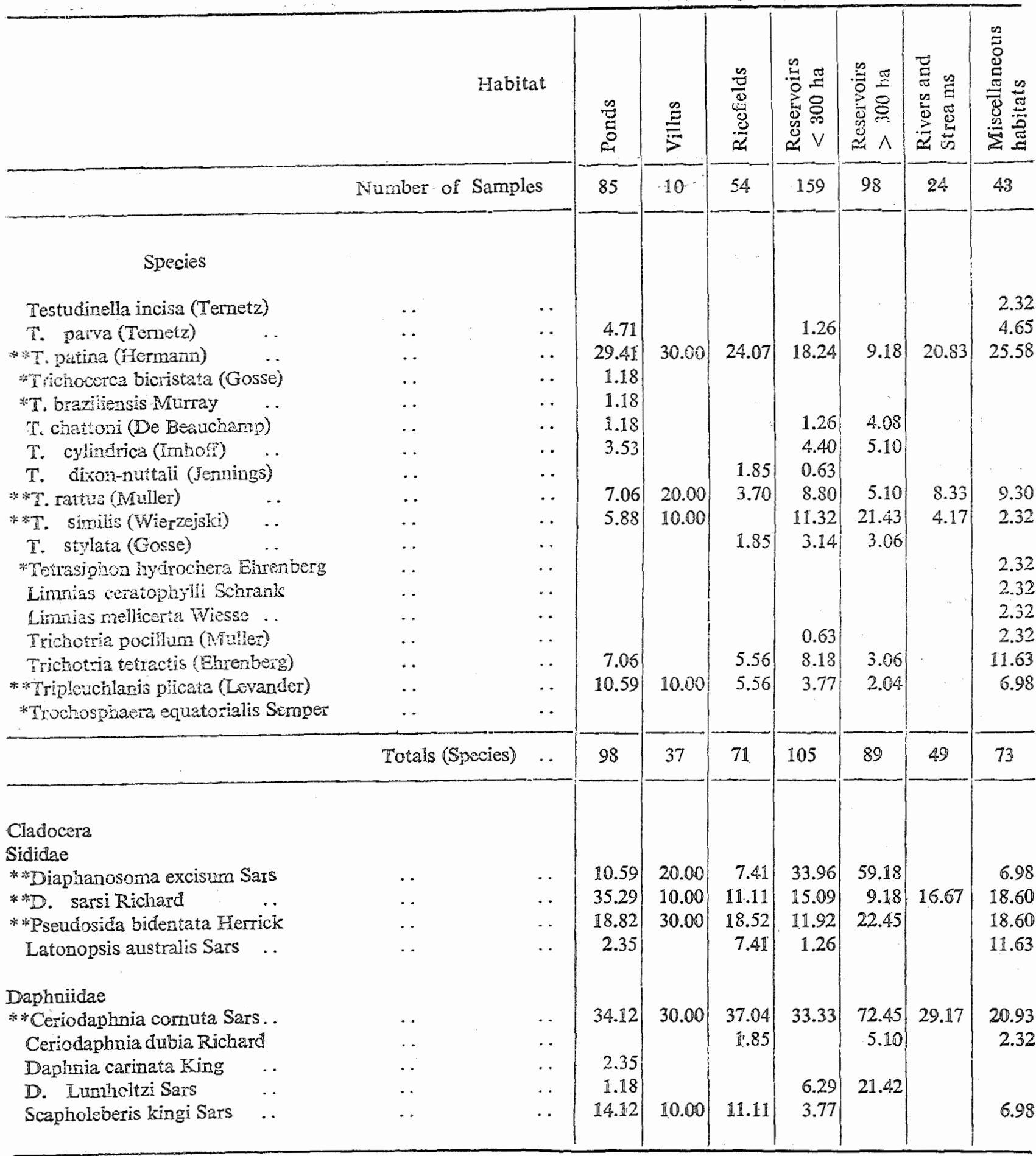

Values below 0.5 are soi included.

Fare $=\left\langle z_{\%}\right.$ (Total occurrence).

$3 *$ Eirytopic = occur in at least sik of the seven habitat tyr.

$X=$ previous records ouly, arot recorded in present study. 


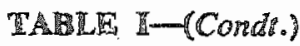

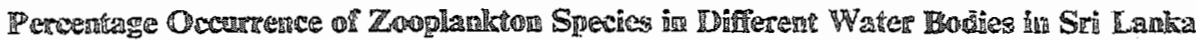

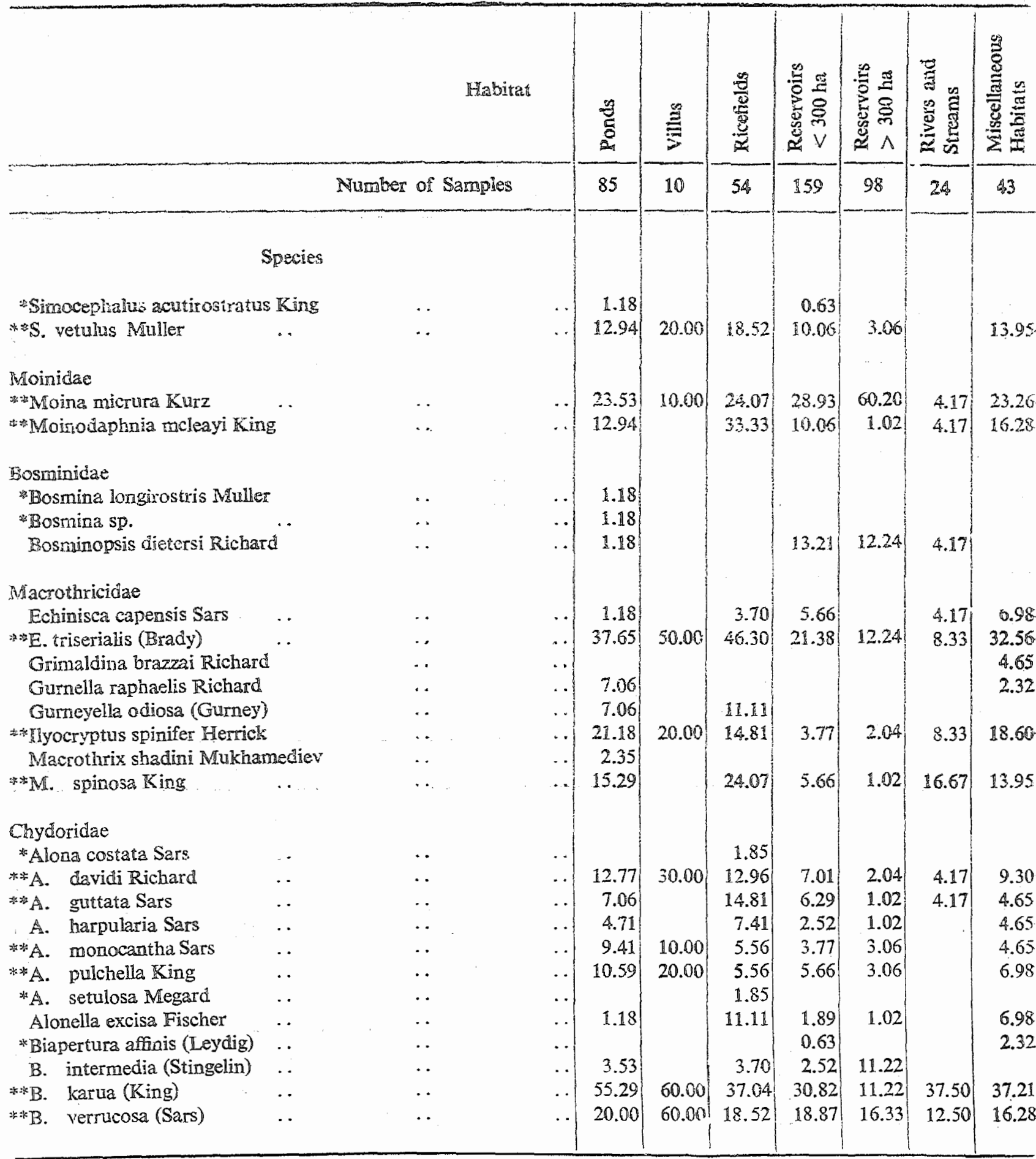

Values below 0.5 are not included.

$\approx$ Rare $=<2 \%$ (Total occurrence).

** Eurytopic $=$ occur in at least six of the seven habitat types.

$\mathrm{X}=$ previous records only, not recorded in present study. 
THAR

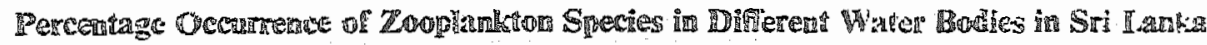

\begin{tabular}{|c|c|c|c|c|c|c|c|c|c|}
\hline & \multicolumn{2}{|c|}{ Rliabitat } & 苞 & $\stackrel{\infty}{3}$ & $\begin{array}{l}\frac{8}{8} \\
\frac{8}{8} \\
2\end{array}$ & 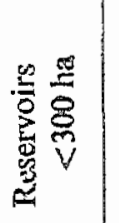 & 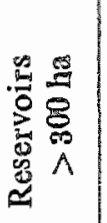 & 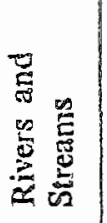 & 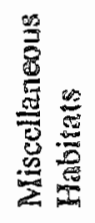 \\
\hline & \multicolumn{2}{|c|}{ Nimber of Samples } & 85 & 10 & 54 & 159 & 98 & 24 & $A z$ \\
\hline \multicolumn{10}{|l|}{ Syectisi } \\
\hline Chydorus barriosi Richand . . & . &. & 29.41 & 40.00 & 42.59 & 27.04 & 28.57 & 37.50 & 34.88 \\
\hline$\Rightarrow \mathrm{Ch}$. eurynotus Sars & . & $\ldots$ & 32.94 & 20.00 & 27.78 & 27.67 & 10.20 & 48.83 & 39.53 \\
\hline * *h. parvus Daday & . & $\ldots$ & 17.65 & 10.00 & 27.78 & 11.32 & 1.02 & 4.17 & 13.95 \\
\hline$* *$ Ch. sphaericus Muller $\quad \ldots$ & . & $\therefore$ & 7.06 & & 7.41 & 6.29 & 7.14 & 4.17 & 2.32 \\
\hline$\approx$ a Ch. ventricosus Daday $\quad \ldots$ & . & .. & 11.76 & 10.00 & 7.41 & 10.69 & 4.08 & & 6.98 \\
\hline Daciaya macrops (Daday) & . & $\ldots$ & 10.59 & 10.00 & 11.11 & 3.77 & 1.02 & & 6.98 \\
\hline$\Rightarrow$ Dunhevedia crassa King .. & . & $\cdots$ & 9.41 & & 5.56 & 1.26 & 2.04 & 4.17 & 4.65 \\
\hline D. sertata Daday & . & $\therefore$ & 4.88 & & 1.85 & 1.89 & & 4.17 & 6.98 \\
\hline Euryalona orientalis (Daday) & . & . & 2.35 & & 3.70 & 2.52 & & & 2.32 \\
\hline Graptoleberis testudinaria (Fischer) & . & $\ldots$ & $\mathrm{X}$ & & & & & & \\
\hline *Indialona globulosa (Daday) & $\cdots$ & $\cdots$ & 3.53 & 20.00 & 3.70 & 6.92 & 1.02 & 20.83 & 4.65 \\
\hline *Indialona macronyx (Daday) & . & $\ldots$ & $\mathrm{X}$ & & & & & & \\
\hline Kurzia longirostris (Daday) & . & $\ldots$ & 10.59 & & 1.85 & 3.77 & 2.04 & & \\
\hline Leydigia australis Sars . & . & .. & 4.71 & 30.00 & 3.70 & 8.80 & 4.08 & & 6.98 \\
\hline L. acanthocercoides (Fischer) & . & $\cdots$ & 3.53 & & 1.85 & 1.26 & 2.04 & & 2.32 \\
\hline Oxyurella sinhalensis (Daday) & . & $\cdots$ & 2.35 & 10.00 & 16.67 & 5.03 & 1.02 & & \\
\hline * Plenroxus similis Vavra & . & $\ldots$ & & & & 1.26 & & & \\
\hline \multirow[t]{2}{*}{ Pseudochydorus globosus (Baird) } & - & $\cdots$ & & & 1.85 & 0.63 & 1.02 & & \\
\hline & Total (Species) & $\cdots$ & 48 & 22 & 41 & 43 & 36 & 20 & 38 \\
\hline \multicolumn{10}{|l|}{ COPEPODA } \\
\hline \multicolumn{10}{|l|}{ Cyclopoda } \\
\hline Ectocyclops phaleratus (Koch) & . & $\ldots$ & 1.18 & & 16.67 & & 1.02 & & 9.30 \\
\hline Eucyclops serrulatus (Fischer) & . & $\ldots$ & 3.53 & & 3.70 & 1.89 & & 4.17 & 4.65 \\
\hline Macrocyclops distinctus (Richard) & . & $\ldots$ & 2.35 & & 5.56 & & & & 2.32 \\
\hline *:Mesocyclops leuckarti (Claus) & . & $\ldots$ & 77.65 & 70.00 & 72.22 & 77.36 & 89.80 & 75.00 & 86.05 \\
\hline *Metacyclops minutus (Claus) & . & $\cdots$ & & & 1.85 & & & & \\
\hline *Microcyclops moghulensis Lindberg & . & $\cdots$ & & & 1.85 & & & & \\
\hline * Microcyclops varicans Sars & .. & $\cdots$ & 51.76 & 50.00 & 61.11 & 27.04 & 5.10 & 25.00 & 60.47 \\
\hline Paracyclops fimbriatus (Fischer) & . & $\cdots$ & 1.18 & & 5.56 & 0.63 & & 4.17 & 4.65 \\
\hline * Thermocyclops crassus (Fischer) & . & $\ldots$ & 25.88 & & 16.67 & 20.13 & 48.98 & 16.67 & 44.19 \\
\hline **Tropocyclops prasinus (Fischer) & . & $\ldots$ & 12.94 & 10.00 & 16.67 & 5.03 & 4.08 & 4.17 & 23.26 \\
\hline Tropocyclops confinis (Kiefer) & - & $\ldots$ & & & & 5.03 & & & \\
\hline
\end{tabular}

Values below 0.5 are not included.

$*$ Rare $=<2 \%$ Total occ Issence.

Eur $y$ topic $=0 c c u r$ in at least $\mathrm{six}$ of the seven habitat types.

$\mathrm{X}=$ previous records only, not recorded in present study. 
TABLF $耳$ - Contd. $)$

Percentage Occurrence of Zooplankton Species in Difierent Water Bowlies in Sri Lavira

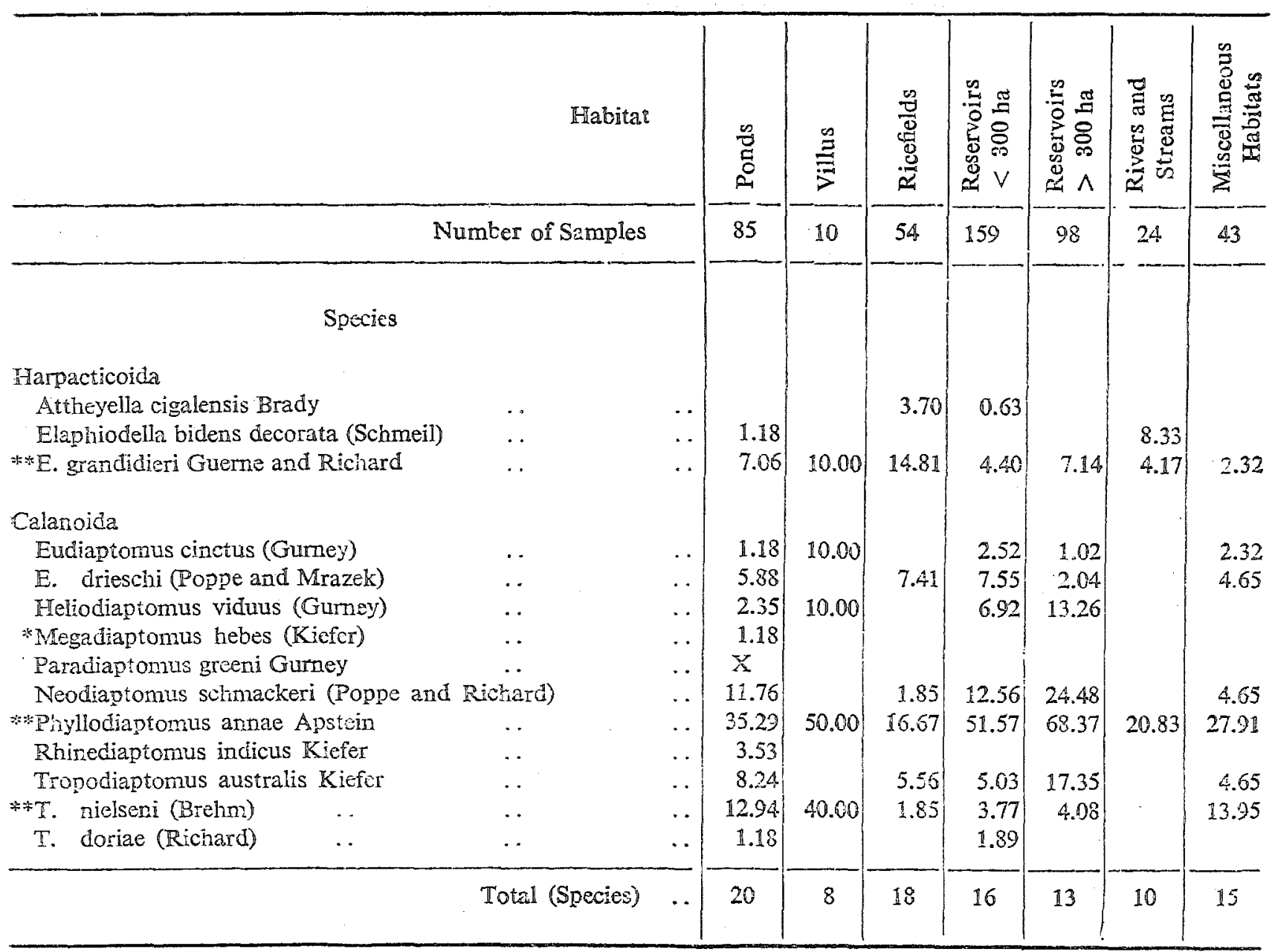

Values below 0.5 are not included.

*Rare $=<2$ per cent (Total occurrence).

**Eurytopic occur in at least six of the seven habitat types.

$X=$ previcus records only, not recorded in present study. 
TABLI II

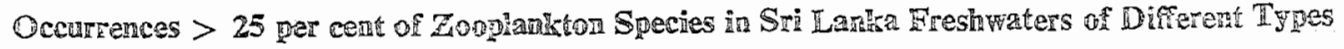
(Numbers ro:nded off to nearest whole number)

\begin{tabular}{|c|c|c|c|c|c|c|c|c|c|}
\hline & & Habitat & \multirow{2}{*}{$\frac{\stackrel{\infty}{\vec{S}}}{85}$} & \multirow{2}{*}{ 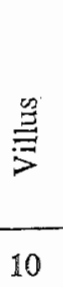 } & \multirow{2}{*}{$\frac{\frac{9}{3}}{\frac{g}{g}}$} & \multirow{2}{*}{ 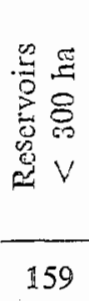 } & \multirow{2}{*}{ 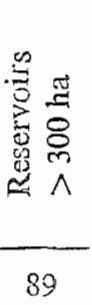 } & \multirow{2}{*}{ 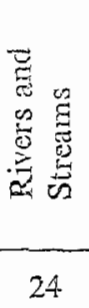 } & \multirow{2}{*}{ 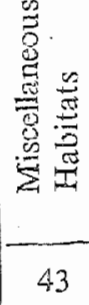 } \\
\hline & & Number of Samples & & & & & & & \\
\hline \multicolumn{10}{|c|}{ Species } \\
\hline Rotifera & & & & & & & & & \\
\hline Asplanchna brightwelli & .. & .. & & & & 27 & 30 & & \\
\hline Brachionus angularis & .. & .. & & & & & 34 & & \\
\hline B. calyciflorus & .. & .. & & & & 28 & 51 & & \\
\hline B. caudatus & .. & . & & & & & 26 & & \\
\hline B. falcatus & .. & .. & & & & 38 & 69 & & \\
\hline B. forficula & .. & .. & & & & 26 & 71 & & \\
\hline B. patulus & .. & .. & 34 & 40 & 28 & & & & 30 \\
\hline B. quadridentatus & . & .. & & 30 & & & & & \\
\hline Euchlanis dilatata & .. & .. & 38 & 40 & 48 & 33 & & 25 & 44 \\
\hline Filinia opopliensis & .. & . & & & & & 27 & & \\
\hline Hexarthra intermedia & .. & .. & & & & & 31 & & \\
\hline Keratella tropica & .. & .. & & 40 & & 42 & 81 & & \\
\hline Lecane hornemanni & .. & .. & & 30 & & & & & \\
\hline $\mathbb{L}$. luna.. & .. & .. & 33 & 60 & & & & & 39 \\
\hline I. ungulata & .. & .. & & & 28 & & & & \\
\hline L. bulla .. & .. & .. & 51 & 60 & 43 & 45 & 41 & 58 & 58 \\
\hline L. lunaris & .. & . & & 30 & & & & & \\
\hline I. unquitata & . & .. & & 40 & & & & & 33. \\
\hline Platyias quadricornis & .. & .. & 35 & & 30 & & & 25 & \\
\hline Pompholyx complanata & .. & .. & 26 & & & 27 & 34 & 38 & 35. \\
\hline Testudinella elliptica & .. & .. & 29 & 30 & & & & & 26 \\
\hline \multicolumn{10}{|l|}{ Cladocera } \\
\hline Diaphanosoma excisum & .. & .. & & & & 34 & 59 & & \\
\hline D. Sarsi & .. & . & 35 & & & & & & \\
\hline Pserudosida bidentata & .. & .. & & 30 & & & & & \\
\hline Ceriodaphnia cornuta & .. & .. & 34 & 30 & 37 & 33 & 72 & 29 & \\
\hline Moina micrura & .. & .. & & & & 29 & 60 & & \\
\hline Moinodaphnia mcleayi & .. & .. & & & 33 & & & & \\
\hline Macrothrix triserialis & .. & .. & 38 & 50 & 46 & & & & \\
\hline Alona punctata & .. & .. & & 30 & & & & & \\
\hline Biapetura karua & .. & .. & 55 & 60 & 37 & 31 & & 38 & 37 \\
\hline B. verrucosa & .. & .. & & 60 & & & & & \\
\hline Chydorus barriosi & .. & .. & 29 & 40 & 41 & 27 & 29 & 38 & 35 \\
\hline Ch. eurynotus & .. & .. & 33 & & 28 & 28 & & 49 & \\
\hline Ch. parvus & .. & .. & & & 28 & & & & \\
\hline Leydigia australis & .. & .. & & 30 & & & & & \\
\hline \multicolumn{10}{|l|}{ Copepoda } \\
\hline Mesocyclops leuckarti & . & $\therefore$ & 78 & 70 & 72 & 77 & 90 & 75 & 86 \\
\hline Microcyclops varicans & .. & .. & 52 & 50 & 61 & 27 & & 25 & 60 \\
\hline Thermocyclops crassus & .. & .. & 26 & & & & 49 & & 44 \\
\hline \multicolumn{10}{|l|}{ Calanoida } \\
\hline Phyllodiaptomus annae & .. & .. & 35 & 50 & & 52 & 68 & & 28 \\
\hline
\end{tabular}


TABLE UII

Percentage Occurrence of Some Genera, Species and Growps of Fawna im the Planiton Samples collected in Sri Lanka, 1965-1979

(The occurrence of more than one member of a group is listed as a single occurrence.)

\begin{tabular}{|c|c|c|c|c|c|c|c|c|c|}
\hline \multicolumn{3}{|r|}{ Ilabitats } & 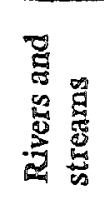 & $\begin{array}{l}\stackrel{\infty}{\overparen{Z}} \\
\stackrel{0}{0}\end{array}$ & $\stackrel{\text { 层 }}{3}$ & 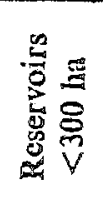 & 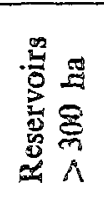 & $\begin{array}{l}\frac{0}{3} \\
\frac{8}{8} \\
\frac{8}{2}\end{array}$ & 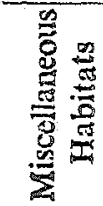 \\
\hline \multicolumn{3}{|c|}{ Number of Samples } & 24 & 85 & 10 & 89 & 159 & 54 & 43 \\
\hline \multicolumn{10}{|c|}{ Gemera, Species and Groups } \\
\hline \multicolumn{10}{|c|}{ Protozoa } \\
\hline "Distugia .. & $\therefore$ & & 12 & 02 & - & - & 02 & - & - \\
\hline Arcelli & .. & .. & 58 & 44 & 03 & 23 & 37 & 31 & 44 \\
\hline Centropyxis & .. & .. & 50 & Ol & - & 02 & 08 & 05 & 14 \\
\hline \multicolumn{10}{|l|}{ Colenterata } \\
\hline \multirow{2}{*}{\multicolumn{10}{|c|}{ Platyhelrninthes }} \\
\hline & & & & & & & & & \\
\hline Rhabdocoela & .. & .. & - & 82 & - & 02 & 04 & 10 & 14 \\
\hline Tricladida .. & .. & .. & - & - & - & - & - & - & - \\
\hline \multicolumn{10}{|l|}{ Petoprocta } \\
\hline Pluñutella repens $\mathrm{E}$ & & .. & 25 & 14 & 60 & 14 & 14 & 07 & 16 \\
\hline * Lophobodella carter & (Hyatt) & .. & - & - & - & 01 & .06 & - & - \\
\hline Nematoda $\quad .$. & .. & .. & 25 & 16 & 40 & 01 & 15 & 15 & 14 \\
\hline Hirudinea .. & .. & .. & - & 01 & - & - & - & $\ldots$ & - \\
\hline Oligochaeta .. & .. & .. & 25 & 24 & - & - & 15 & 22 & 32 \\
\hline Mollusca $\quad$. & .. & .. & - & 03 & 10 & 01 & 03 & 02 & 07 \\
\hline Conchostraca.. & .. & .. & - & 03 & - & - & - & - & - \\
\hline \multicolumn{3}{|c|}{ Cyclestheria hislopi (Baird) } & - & 02 & - & - & .06 & 05 & - \\
\hline Anostraca .. & $\ldots$ & .. & - & 02 & - & - & - & - & - \\
\hline Ostracoda $\quad \ldots$ & .. & .. & 20 & 55 & 60 & .06 & 20 & 57 & 48 \\
\hline Decapoda (Caridina) & .. & .. & 08 & 04 & 30 & 05 & 02 & 05 & 02 \\
\hline \multicolumn{10}{|l|}{ Insecta } \\
\hline Ephemeroptera & .. & .. & - & 11 & 30 & 03 & 08 & 24 & 14 \\
\hline Odonata .. & .. & .. & - & 13 & 20 & 02 & .06 & 12 & 20 \\
\hline Hemiptera & .. & .. & 25 & 25 & - & 03 & .06 & 06 & 20 \\
\hline \multicolumn{10}{|l|}{ Diptera } \\
\hline Culicidae .. & .. & .. & 12 & 09 & - & 01 & 02 & 20 & 23 \\
\hline "Chaoborus & .. & .. & - & 03 & - & 17 & 04 & - & 02 \\
\hline *Chironomidae & $\therefore$ & .. & 58 & 37 & - & 20 & 23 & 44 & 37 \\
\hline Heleidae .. & .. & .. & 04 & 03 & - & 01 & 02 & 12 & 07 \\
\hline Strationyidae & .. & .. & - & - & - & - & - & - & 02 \\
\hline \multicolumn{10}{|l|}{ Coleoptera } \\
\hline Hydrophilidae & .. & .. & - & 06 & - & - & - & - & - \\
\hline Noteridae .. & .. & .. & - & 03 & - & 01 & .06 & 02 & 02 \\
\hline Dytiscidae & .. & .. & - & - & - & - & .06 & 15 & 02 \\
\hline \multicolumn{10}{|l|}{ Arachnida } \\
\hline Hydracarina & .. & .. & 20 & 20 & 20 & 22 & 23 & 20 & 18 \\
\hline Tardigrada .. & .. & .. & - & D1 & - & - & .06 & - & 02 \\
\hline \multicolumn{10}{|l|}{ Parasites } \\
\hline$*$ Paraergasilus brevid & itus Yin & .. & - & - & - & 01 & ol & - & - \\
\hline *Ergasilus sp. & .. & .. & - & - & - & 01 & .06 & - & - \\
\hline Lernaea cyprinacea & .. & .. & - & - & - & - & .06 & - & - \\
\hline *Lamproglena sizens & Yu. .. & $\theta$ & - & 一 & - & - & .06 & - & - \\
\hline
\end{tabular}

NPlanktonic at some stage of life or throughout life cycle. 


\section{TABLE IV}

\section{Composition of the Cladloceran Fauna of Some South-East Asiam Countries and Temperate Regions}

(A comparison is also given of the limnetic species in tropical Asian and Holarctic regions. Tropical "India" is compared with Northem India. India = Indian sub-continent. The total number of Cladocera species in Indonesia is about 65 and in the Philippines 49 are known with a probable total of about 55.)

\begin{tabular}{|c|c|c|c|c|c|c|c|c|c|}
\hline \multirow{2}{*}{\multicolumn{2}{|c|}{ Area and Type }} & \multicolumn{2}{|c|}{ Tropical } & \multicolumn{2}{|c|}{ Temperate } & \multicolumn{2}{|c|}{$\begin{array}{l}\text { Planktonic } \\
\text { Species }\end{array}$} & \multicolumn{2}{|c|}{ India } \\
\hline & & 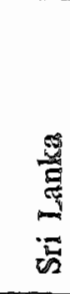 & $\frac{\sqrt{5}}{\frac{5}{2}}$ & 茎 & 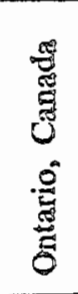 & 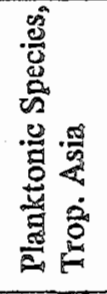 & 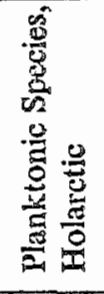 & 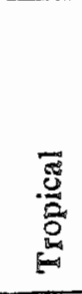 & 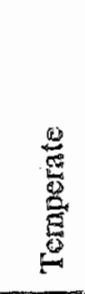 \\
\hline \multicolumn{2}{|c|}{ Total No. of Species } & 56 & 58 & 88 & 92 & 10 & 36 & 62 & 52 \\
\hline \multicolumn{10}{|c|}{ Families, Genera } \\
\hline Holopedidae & .. & 0 & 0 & 直 & $\mathbb{1}$ & 0 & 1 & 0 & a \\
\hline Polyphemidae & .. & 0 & 0 & 3 & 1 & 0 & 3 & 0 & $\mathbb{1}$ \\
\hline Leptodoridae & . & 0 & 0 & $\mathbb{1}$ & 1 & 0 & 1 & 0 & 1 \\
\hline \multicolumn{10}{|l|}{ Daphniidae } \\
\hline Daphnia & .. & 2 & 1 & 10 & 12 & $\mathbb{1}$ & $18^{*}$ & 2 & 6 \\
\hline Ceriodaphrnia & .. & 2 & 2 & 8 & 8 & 2 & 4 & 2 & 4 \\
\hline Others & .. & 4 & 3 & 5 & 5 & 0 & 0 & 3 & 1 \\
\hline \multicolumn{10}{|l|}{ Sididae } \\
\hline Diaphanosoma & .. & 2 & 4 & 1 & 1 & 3 & $\mathbb{1}$ & 4 & 1 \\
\hline Others & .. & 2 & 2 & 2 & 6 & (i) & 0 & 3 & $\mathbb{1}$ \\
\hline Bosminidae & .. & 2 & 1 & 2 & $\$$ & 2 & $T^{*}$ & 2 & 2 \\
\hline Moinidae & .. & 3 & 3 & 3 & 1 & 1 & 0 & 4 & 2 \\
\hline Chydoridae & .. & 31 & 35 & 41 & 41 & $1+$ & $1 \pm$ & 34 & 26 \\
\hline Macrothricidae & .. & 8 & 8 & $\mathbb{1 I}$ & 11 & 0 & 0 & 8 & 6 \\
\hline
\end{tabular}

Fauna poorly studied.

In temperate regions, Chydorus sphaericus is often found in numbers in the plankton. Ta tropical South-East. sia Ch. barroisi is found instead. 


\section{TABHE}

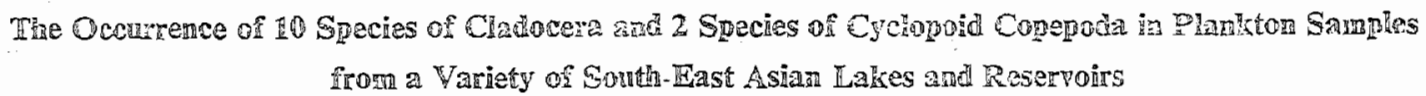

(All other species and the number of times they occur in samples are given similar numbers for the species lisied are also given. Numbers in parentheses refer to the total number of species involved in the occurrences listed. The high values for Malaysian and Sri Lankan reservoirs indicate that littoral species were involved.)

\begin{tabular}{|c|c|c|c|c|c|c|c|c|c|c|c|c|}
\hline \multirow[b]{2}{*}{$\begin{array}{l}\text { Lakes, } \\
\text { Reservoirs, } \\
\text { Plankion }\end{array}$} & \multicolumn{6}{|c|}{ Individual Lakes } & \multicolumn{6}{|c|}{ Groups of Lakes } \\
\hline & 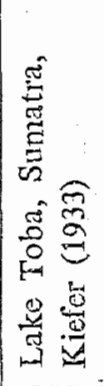 & 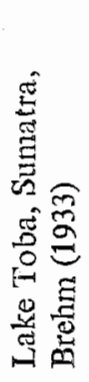 & 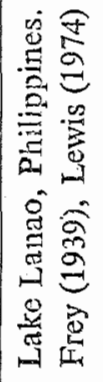 & 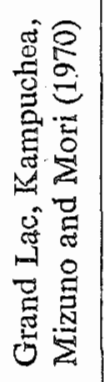 & 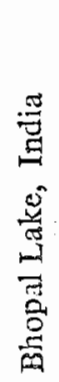 & 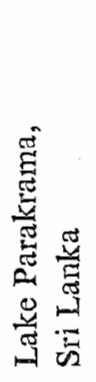 & 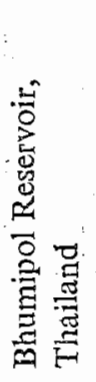 & 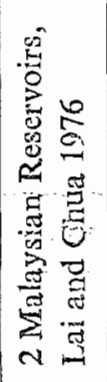 & 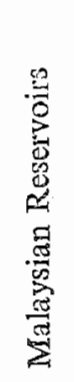 & 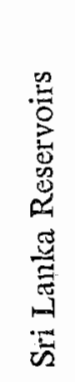 & 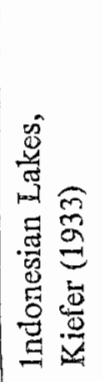 & 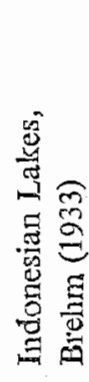 \\
\hline Nuniver of Samples & 3 & $?$ & $?$ & $?$ & 28 & 7 & 5 & $?$ & 33 & 98 & 16 & 12 \\
\hline \multicolumn{13}{|l|}{ Species } \\
\hline Cladocera & & & & & & & & & & & & \\
\hline Diaphanosoma sarsi .. & - & + & - & - & - & + & + & + & + & + & - & + \\
\hline D. excisuin & - & - & - & + & + & + & + & + & + & + & - & + \\
\hline $\begin{array}{l}\text { D. modig } / \text { iani } \\
\text { Ceriodaph nia cornuta: }\end{array}$ & - & + & + & - & - & - & - & - & - & - & - & + \\
\hline $\begin{array}{l}\text { Ceriodaph nia cornuta } \\
\text { Ceriodaphnia dubia ... }\end{array}$ & - & - & - & + & + & + & + & + & + & + & - & + \\
\hline Ceriodaphnia dubia .. & - & + & - & - & - & - & - & - & - & + & - & + \\
\hline Moina micrura . .. & - & - & + & + & + & + & - & + & + & + & - & + \\
\hline Bosmina longirostris .. & - & + & + & - & + & - & - & - & - & + & - & + \\
\hline Bonninopsis dietersi & - & - & + & + & - & - & - & - & + & + & - & + \\
\hline Daphnia lumholtzi .. & - & - & - & - & + & + & - & - & 一 & + & - & 一 \\
\hline $\begin{array}{l}\text { Other Dapinnia sp. .. } \\
\text { Total Occurrences }\end{array}$ & $\bar{c}$ & - & - & - & - & - & - & - & + & - & - & - \\
\hline $\begin{array}{l}\text { Species } \times \text { Oudurrences } \\
\text { Other Species than above }\end{array}$ & $\frac{5}{8}$ & & & & 68 & 20 & 13 & & 53 & 235 & 告 & 21 \\
\hline Species $\times$ Occurrences & $\vec{b}$ & $\mathbb{1}$ & 0 & & $\begin{array}{r}16 \\
(7)\end{array}$ & $\begin{array}{r}6 \\
(5)\end{array}$ & $\begin{array}{r}1 \\
\text { (1) }\end{array}$ & $\begin{array}{r}2 \\
(2)\end{array}$ & $\begin{array}{r}97 \\
(32)\end{array}$ & $\begin{array}{l}154 \\
\text { (29) }\end{array}$ & 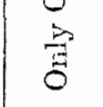 & $\begin{array}{r}4 \\
(3)\end{array}$ \\
\hline $\begin{array}{l}\text { Cyclopoid Copepoda } \\
\text { Thermocyclops crassus }\end{array}$ & + & & + & $+?$ & + & + & $\div$ & + & + & + & + & \\
\hline Mesocyclops leuckarti & + & & $+?$ & + & + & + & + & $\dot{T}$ & + & + & + & \\
\hline $\begin{array}{l}\text { Total Occurrences } \\
\text { Species } \times \text { Occurrences } \\
\text { Others Species than above }\end{array}$ & 6 & $\begin{array}{l}0 \\
\frac{0}{0} \\
\frac{0}{0} \\
\frac{5}{0} \\
\frac{3}{2}\end{array}$ & $?$ & 2 & 54 & 9 & 9 & $?$ & 127 & 138 & 28 & 总 \\
\hline Species $\times$ Occurrences & $\begin{array}{r}\mathbb{1} \\
\text { (1) }\end{array}$ & $\vec{B}$ & $?$ & $?$ & 0 & $\begin{array}{r}1 \\
(1)\end{array}$ & 0 & 0 & $\begin{array}{r}36 \\
(4)\end{array}$ & $\begin{array}{r}10 \\
(3)\end{array}$ & $\begin{array}{r}6 \\
(3)\end{array}$ & 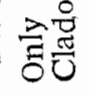 \\
\hline
\end{tabular}




\section{APPENDHX II}

Sampling Localicies in Sri Lanka $1968-1975$

The type of habitat is indicated as follows: 1 . Rivers and Streams; 2. Ponds; 3. Villus (Natural habitats): 4. Lakes $>300 \mathrm{ha} ; 5$. Lakes $<300 \mathrm{ha} ; 6$. Ricefields (Manmade habitats); 7. Miscellaneous habitats :- Wells, Gem pits, Rainpools, etc. Provinces : Central (C); Sabaragamuwa (Sab); Eastern (E); Southern (S); Western.(W); North Western (NWP); North Central (NCP); Northern (N) ; Uva (Uva). 1965 samples collected by Dr. D. G. Prẹ. Includes also miscellaneous samples collected before 1968 .

1. Rivers and Streams

10. Battulu Oya (NWP) : 2. VI. $72,15 . \quad X .72,25 . \quad$ VII. 72

11. Bolawalana, Wennappuwa (NWP), 16. III. 73

12. Belihuloya, (Sab) 16. VIII. 72

13. Buduruwagala aru, Bađdelandeniyaya (Uva) 5. VII. 74.

14. Dambullu Oya, Dambulla (C) 16. VI. 74

15. Hingulu Oya, Hingula (C) 4. VII. 74

16. Kala Oya (NCP) 15 . VI. 74

17. Kottawa Nr. Galle (S) 9. XII. 73

18. Kubal Oya, Diyanawatte Kumbura (C) 22. XII. 73

19. Maha Oya, Amparai (E) 4. VII. 74:

100. Madugoda, N.R. Mahiyainganne (C) 5 . VII. 74

101. Maya Oya, Dambadeniya-Padiyatalawa Road (E) 5. VII. 74

102. Mirisgama Oya Dambulla-Anuradhapura Road. (C) 16. VI. 74

103. Moongal aru Nr. Mrulativu (N) 22. IV. 74

103.1 Mullativu, Nandi Kađel Freshwater Entering Lagoon (N) 22. IV. 74

104. Mullativu-Paranthan Road Culverí $7 / 3$ (N) 22. IV. 74

105. Mullativa-Paranthan Road before 4/9 Culvert (N) 22. IV. 74

106. Nochchiyagama (NCP) 15 . VI. 73

107. Paranthan-Jaffina Road $26 / 1$ (N) 22. IV. 74

108. Ratmaloya Nr. Madampe (Chilaw) (NWP) 28. XI. 73

109. Thanniyootu, Mulativu (N) 22. IV. 74:

110. Uheliya Oya, Dumbara (Uva) 15. IV. 74

111. Yaticalan Oya, Bogahakumbura Near Kurunegala (NWP) 30. XI. 73

2. Ponds

20. Agampitiya (NWP) 16. III. 73

21. Anuradhapura, Lotus pond (NCP) 4. I. 65

22. Anuradhapura, pond in Mioat (NCP) 5. V. 73

23. Anuradhapura, Pond Near Archaeological Museum (NCP) 5. V. 73

24. Badulla, Shannon Estate (Uva) 1. I. 65

25. Balangoda (Sab) 16. VIII. 72

26. Battulu Oya (NWP) 24. XIII. 70

27. Battulu Oya, Coconut estate (NWP) 24. XII. 70

28. Batugedera Near Ratnapura (Sab) 19. VIII. 72

29. Bibilideniya Near Nattandiya (NWP) 18. VIII. 71

200. Bolawalana Panchchankuliya, (NWP) 16. III. 73

201. Bolawalana Panchchankuliya Pond 2 (NWP) 16 . III. 73

201.1 Chavakachcheni-Karativu Road Jafina (N) 26. XII. 73

202. Colombo, Queen Victoria Park (W) 31. XII. 64

202.1 Dothalla, Mahawewa, Hettipola (NWP) 16. XII. 72

203. Eppawela (NCP) 11 . VIII. 72

203.1 Ensalwatte, Deniyaya (Sab)

204. Gurugoda, Millewa-Padukka Road (W) 23. XIII. 72

205. Gurugoda Nr. Horana (W) 23. XII. 72

5-A $45286(80 / 03)$ 
205. Handapangal: (Uva) 28. XII. 70

207. Hlorana Nr. Pillyandala (W) 23. XIII. $72=210$

207.1 Hunnelama, Mahawewa (NWP) 7. XIII. 72

208. Ilavalai, Jaffina Peninsula (N) 17. XII. TI

208.1 "Jaffina" 1974 ; Pond 31974 ; Decemher 1975

209. Kahalla, Near Katugastota (C) 26. X. 72

"210. Kahataduwa, Near Horana (W) 23. XII. 72

211. Kalpitiya, Near Paraidi (NWP) 15. X. 72

212. Kalpitiya (NWP) 25. VII. 71

213. Kammala, Near Wennappuwa (NWP) 6. III. 73

214. Kanneliya, Near Udugama (S) 14. VII. 72

215. Karainagar, Jafina Near Jetty (N) 15. XII. 71

216. Kayts, Jaffina (N) 17. XII. 72

217. Kodikamam, Jaffina (N) 16. XII.

218. Madurankuliya Near Hindu temple (NWP) 15. X, 72

219. Madurankuliya, Lotus pond (NWP) 1. VI. 72

220. Madurankuliya, Pond 2 (NWP) 2. VI. 72

221. Mankumban, Near Mandativu, Jaffina (N) 17. Xil. 71

222. Mannar (N) 18. XII. 70

223 ?

ito Yarawila, small ponds (NWP) 29. XI. 72;6. XII. 72;1. VII. 73 225. j

226. Marawila, Pitchchaswamala (NWP) 7. XII. 70

227 Marawila ponds (NWP) 6. XII. 70;6. XII. 70 and 6. IX 70 (2 samples); 22 . VII. $72 ; 1$. VI 232. $73 ; 18 . \mathbb{1 1 I} .73 ; 5$. V. $73 ; \mathbb{1 1} . \mathbb{1} .74$

233. Mullativu, on Jaffina road (N) 22. IV. 74

234. Mundel (NWP) $15 . \quad$ X. 72

235. Nainamadama Near Wennappuwa (NWP) 16. III. 73

236. Navakuli, Jafina (N) 16. XII. 71

237. Nikeweratiya (NWP) 16 . XII. 70

238. Nuwara Eliya, Park (C) 21. XII. 73

239. Nuwara Eliya (C) 27. VII. 71

240. Padeniya (NWP) 17. XII. 72

241. Padukka (W) 23. XII. 72

242. Palai, Jaffina (N) 22. IV. $74: 1974$

243. Palavi (NWP) 25. VII. 71

244. Panagoda (W) 23. XII. 72

245. Piliyandala (W) 23. XII. 72

246. Piliyandala Near Horana (W) 23. XII. 72

247. Point Pedro, Jaffna (N) 16. XII. 71

247.1 Polgaswita-Piliyandala Road (W) 23. XII. 72

248. Polonnaruwa, Freshwater Fisheries Station (NCP) 13. III. $62 ; 3.1 .65$

249. Polonnaruwa Near Gal Vihare (NCP) 1. I. 65

250. Punkudativu, Jaffna (N) 17. XII. 71

251. Puttalam, small pond (NWP) 12 . VII. 73

252. Puttalam, pond (NW) 12. VI. 73

253. Saranavai. Iafina (N) 17. XII. 71

254. Tabbowa Near Puttalam (NWP) 25. VII. 71

255. Thanniyootu, Near Mullativu (N) 22. IV. 74

256. Thavady, Jaffina (N) 16. XII. 71

257. Theravai Near Mullativu (N) 22. IV. 74

258. Thiruwanaketiya Near Ratnapura (Sab) 19。VIII. 72 
259. Unichchi (E) 28. 12. 70

259.1 Vaddukoddai, Jafina; (N) 26. VI. 74

260. Vaddukoddai, Jaffina; t temple pond (N) 15. XII. 71

260.1 Vaddukoddai ; Jaffna, (N) 3. I. 74

261. Waga (W) 31 . XII. 70

3. Vidius

30. Kale villu, Wilp.ntiu (NWP) 10. IV. 73 (Saline; no freshwater zooplankton)

31. Karapola villu, Kear Polonnaruwa (NCP) 7.1.72

32. Kokkare villu, Wilpattu (NCP) 10 . IV. 73

33. Marawila, small villu near sea (NWP) 24. $\mathbb{1 1} .73$

34. Marawila, Kudawatuwela villu (NWP) 1. 1.74

35. Perybandi villu Wilpattu (NCP) 14. IV. 73

36. Nelunvillu, Wilpattu (NCP) 10. IV. 73

37. Panikkar villu Wilpattu (NWP) 11 . IV. 73

38. Puttalam (Mahavillu) (NWP) 6. V. 73

39. Talawila villu, Wilpattu (NWP) I1. IV. 73

4. Reservoirs $>300$ ha

40. Amparai $\operatorname{tank}(\mathbb{E}) 3$. VII. $68 ; 6$. VIII. $69 ; 28$. XII. 70;5. VII. 74

41. Castlereagh reservoir (C) 10 . VII. $68 ; 16$. VII. 69

42. Chandrika wewa (Sab) 5. VIII. $68 ; 16$. VII. $69 ; 27$. XII. $70 ; 22 . \mathbb{I} .71$

43 ?

to Giants tank (Yodawewa), Mannar (N) 18. VIII. 68; 5. VIII. 69; 18. XII. 70

44. $j$

45. Horaborawewa (Soraborawewa) (Uva) 10. XI. $72 ; 4$. VII. 74

46. Iranamadu tank (N) 16. VII. 68 ; 3. III. $69 ; 22$. III. 71

47. Kalawewa (NCP) 3. I. $65 ; 18$. XII. $70 ; 3$. VIII. $68 ; 6$. VII. 69

48. Kandalama tank (C) 3. VIII. $68 ; 8$. III. $69 ; 28$. XII. $70 ; 16$. VI. 74

49. Kantalai $\operatorname{tank}(\mathbb{E}) 20$. VIII. $68 ; 6$. III. $69 ; 20$. XII. 70

400. Mahakandarawa tank (NCP) 19. VII. $68 ; 20$. XII. $70 ; 15$. VII: 74.

401. Maskeliya reservoir (C) 24. XII. 70

402. Minneriya tank (NCP) 3. VII. $68 ; 20 . X .69 ; 28 . X I I .70$

403. Morawewa (E) 19. VIII. $68 ; 5$. VIII. $69 ; 20$. XII. 70

404. Nachchaduwa tank (NCP) 2. VIII. $68 ; 6$. VII. $69 ; 18$. XII. 70

404.1 Nagadeepa wewa (NCP) 1. X. $72 ; 10$. XI. 72

405. Nalanda reservoir (C) 3. VIII. $68 ; 20$. X. $69 ; 28$. XII. $70 ; 15$. VI. 74

406. Nalanda reservoir (littoral), little vegetation (C) 27. XII. 73

407. Nuwarawewa, Anuradhapura (NCP) 2. VII. $68 ; 6$. VII. $69 ; 19$. XII. $70 ; 12$. VII. 72

408. Padaviya tank (NCP) 17. VIII. $68 ; 5$. III. $69 ; 23$. II. $71 ; 23$. III. 71

409. Parakrama Samudra (NCP) 2. VIII. $68 ; 7$. III. $69 ; 28$. XIII. 70; 6. I. $72 ; 4$. IIII. 72

410. Parakrama Samudra (NCP) 27. X. 57

411. Pavatkulam (N) 17. VIII. $68 ; 4$. III. 69

412. Ridiyagama tank (S) 28. T. 71

413. Senanayake Samudra (Uva) 3. VIII. 68 ; 6. VIII. $69 ; 28$. XIII. 70; 27. I. 71; 5. VII. 7 A

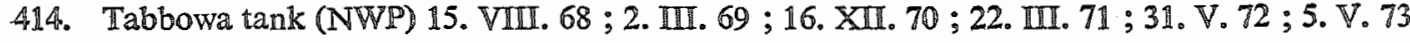

415. Udawalawe reservoir (Uva-Sab) 5. VIII. $68 ; 16$. VII. $69 ; 22$. XII. $70 ; 22$. I. $71 ; 7$. VII. 7 .

4116. Unichchi tank (E) 4. VII. $68 ; 7$. VIII. $69 ; 28$. XII. 70

417. Vakeneri tank (E) 3. VII. 68 ; 7. VIII. $69 ; 28$. XII. 70

418. Vavunikulam (N) 22. III. 71

418.1 Wirawila tank (S) 5. VIII. $68 ; 6$. VII. $69 ; 27$. XII. 70 


\section{Lifforal Samples}

419. Castlereagh reservoir (C) 23. XII. 70

420. Tabbowa tank (NWP) 31. V. 72

421. Udawalawe Reservoir (Uva-Sab) 27. XII. $70 ; 7$. VII. 74

5. Reservoirs $<300$ has

50. Agampitiya wewa (NWP) 16. III. 73

51. Ambiliwewa, Near Kurunegala (NWP) 9. VIII. 68

52. Anabulundawa tank, Near Hettipola (NWP) 11. VII. $71 ; 8$. I. 72

53. Angunuwila tank (NWP) 12. VII. 71.

54. Aranaganwila tank (NWP) 7. I. 72

55. Batalagoda tank (NWP) 2. VIII. $68 ; 8$. III. 69

55.1 Batticaloa lagoon, Saline (E) 7. VIII. 69

56. Boralesgamuwa tank (W) 1. VIII. $68 ; 30$. I. $70 ; 31$. XII. 70 ; 3. XII. 72

57. Bulugala $\operatorname{tank}(\mathrm{C}) \mathbb{1 6}$. VI. 74 .

58. Chadiyantalawa tank (E) 27. I. 7 I

59. Colombo lake (Beira) (W) 31. XII. 64

500. Dambarawa tank (Uva) 4. VII. 74

501. Denagama tank (S) 23.1. 71

502. Dothalla tank (Mahawewa) (NWP) 16. XII. 72

503. Drassastraweliya tank (NCP) 3. I. 65

504. Dummaladeniya tank (NWP) 16. VII. 71

505. Dundambuwewa, Near Nochchiyagama (NWP) 16. VI. 74

506. Dunnage wewa, Near Narawila (NWP) 28. XI. 73

507. Eliya Divulwewa (NCP) 11. VIII. 72

508. Eluvankulam tank (NWP) 13. VI. 73

509. Ensalwatte, Near Deniyaya small catchment (Sab) 11. XII. 73

510. Eppawela tank; littoral (NCP) 11. VIII. 72

511. Eppawela tank (NCP) 11. VIII. 72

512. Galwewa (NCP) 6. XI. 72

513. Gnanakulama, Near Maradankadawela (NCP) 16. VI. 74

514. Habarana tank (NCP) 2.1.65

515. Handapangala (Uva) 5. VIII. 68 ; 10. VII. $69 ; 28$. XII. 70

516. Hasalaka tank (C) 4. VII. 74

517. Hinidurawa tank (E) 27. I. 71

518. Horowapotana tank (NCP) 20. XII. 70

519. Kanakarasen tank (N) 23. III. 71

520. Kande ela reservoir (C) 23. III. 73

521. Kande ela reservoir, littoral (C) 23. III. 73

522. Kalatuwewa reservoir (W) 9. VIII. 68.

523. Kalluvil kulam (N) 22. IV. 74

524. Kandy Lake (C) 10. VII. $68 ; 13$. III. $69 ; 24$. XII. $70 ; 4$. VII. 73

525. Kandy (Uduwatakelle tank) (C) 10. VIII. $68 ; 13$. III. $69 ; 24$. XII. $70 ; 4$. III. $72 ; 28$. XIL. 72 : 4. VII. 74

526. Katugahagalge tank, Near Buttala (Uva) 6. VII. 74

527. Katupotha tank, Near Battuluoya (NWP) 26. VIII. $68 ; 9$. VIII. $71 ; 28$. VIII. 72; 15. VI. 74

528. Kebittigollawa tank (NCP) 19. XII. $70 ; 23$. III. 71

529. Kekirawa tank (NCP) 16. VI. 74

530. Kesbewa wewa (W) 1. VHI. 68 ; 31. XII. 70

531. Kilinochchi tank (N) 19. XII. 70

532. Kiribbanare wewa (Uva) 22. I. 71

533. Rondavattavam kulam (E) 5. VII. 74. 
534. Kumbukkan wewa (NWP) 15. VI. 74

535. Kurunegala wewa (NWP) 9. VIII. $68 ; 8$. III. 69

536. Labugama reservoir (W) 9 . VIII. $68 ; 31$. YIII. 70

537. Lahugala tank (E) 28. VIII. 72

538. Lindawewa, Near Nochchiyagama (NCP) 16. 江. 73

539. Lunuwila tank (NWP) 16. VIII. 71

540. Madampe, Near Chilaw (Kudawewa) (NWP) 8. VIII. $68 ; 26$. VIII. 69

541. Madampe. Near Chilaw (Kudawewa) (NWP) 6. XII. 70

542. Madulla wewa (UVa) 17. XUI. 72

543. Madampe, Near Chilaw (Mahawewa) (NWP) 16. VIII. 71

544. Madurankuliya tank (NWP) 2. VII. 72

545. Magalla wewa (NWP) 15. VIII. $68 ; 2 . \mathbb{I I I} .69 ; 17$. XII. 70

546. Mahaillupulama tank, littoral (NCP) 10. Vul. 72

547. Mahaillupulama tank (NCP) 10. VIII. 72

548. Maha Oya tank, Near Badulla (Uva) 5. VII. 7A

549. Mahiyanganne tank (Uva) 5. VII. 74

550. Mapakada tank (Uva) 10. XI. 72 ; 4. VI. 74

551. Maradanmaduwa tank, Wilpattu (NWP) 11. IV. 73

552. Medawachchiya tank (NCP) 18. VII. $68 ; 4$. III. $69 ; 19$. XII. 70

553. Moonplains reservoir (C) 10. VII. $68 ; 15$. XI. 68

554. Mundel wewa (NWP) 4. I. 65

555. Mylawa wewa (NWP) 30. XI. 73

556. Na-eliya tank, Near Battuluoya (NWP) 8. VIII. $68 ; 26$. VIII. $68 ; 28$. VIII. 70; 5. VIII. 72 ; 25. VIII. 72 ; April 1973

558. Naula tank (C) 15 . VI. 74

559. Navagiriyawa wewa (E) 22. T. 71

560. Nochchiyagama wewa (NCP) 16. VI. 74

561. Norton Bridge reservoir (C) 11 . VIII. $68 ; 15$. VIII. $69 ; 23$. XII. 70

562. Nuwara Eliya lake, littoral (C) 23. XII. 70

563. Nuwara Eliya lake (C) I. I. $65 ; 10$. VII. $68 ; 15$. XI. $68 ; 23$. XII. $70 ; 1$. X. 72

564. Pahalamaharagaswewa (NCP) 22. II. 71

565. Pahariya tank, Near Puttalam (NWP) 15. VI. 74

566. Pannegamuwa tank (S) 5. VIII. 68

567. Pelvehera tank (NCP) 2. I. 65

568. Pikulam, Near Mullativu (N) 22. IV. 74

569. Pinkattiya tank, Near Chilaw (NWP) 17. VII. 71 ; 11. VII. 71

570. Punewa tank (NCP) 22. III. 71

571. Punchivillu tank, littoral (NWP) 1. VI. 72

572. Punchivillu tank (NWP) 1 . VI. 72

573. Punchuttuwa tank (NCP) 23. III. 71

574.) Rambewa, (=Rambewewa) Near Nochchiyogama (NCP) 6. V. 73 ; 22. III. 71 :

575. 115 . VI. 74

576. Rotawewa, Keselpotha (Uva) 10. XI. 72

577. Sellakandel tank, Near Puttalam (NWP) 15. VI. 74

578. Sigiriya tank (C) 3.1 II. 72

579. Sooriya wewa (S) 22. I. 71

580. Tammana wewa, Near Puttalam (NWP) 5. V. 73

581. Tellula tank (Uva) 7. VII. 74

582. Thinipitiwewa, Near Chilaw (NWP) 22. VIII. 70;16. VIII. 71; 15. X. 72;3. IX.73 
583. Tirippane tank (NCP) 16. VI. 74

584. Timbiri wewa, Near Nochchiyagama (NCP) 376. $\mathrm{V}$.

585. Tissawewa (NCP) 22. III. 71; 15. VI. 74

586. Thovaramudai, Near Nedunkeni (N) 2. V. 72

587. Udagamuwa tank, Near Buttala (Uva) 7. VII. 74

588. Udaliyagama tank, Near Kekirawa (NCP) 16. VI. 74

589. Ulankulama, Maradankadawela (NCP) 16. V1. 74

590. Urusita tank (S) 22. I. 71

591. Valiwewa, Near Nochchiyagama (NCP) 10. VI. 73

592. Walahapitiya wewa, Near Nattandiya (NWP) 30. XI. 73

593. Wallagama tank (Uva) 27. 1. 71

594. Watugahamulla tank, Near Chilaw (NWP) 30. XI. 73

595. Weeraketiya tank (S) 23. III. 71

596. Wennappuwa tank (NWP) 23. III. $71 ; 16$. VIII. 71

6. Ricefields

60. Alankulama, Near Anuradhapura (NCP) 12. VIII. 72

61. Allipiddy, Near Mandativu (N) 17. XII. 71

62. Balangoda (Sab) 16. XII. 73

63. Battuluoya (NWP) 28. VIII. 72

64. Bellanwila, Near Ratmalana (W) 23. XIII. 72

65. Belihuloya (Sab) 16. VIII. 72

66. Chavakachcheri Jaffna (N) 5.I. 75

66.1 Deniyaya (S) 13. XI. 73

67. Divulwewa, Near Anuradhapura 11. VIII. 72

68. Dothalla (NWP) 16. XM. 72

69. Ensalwatte, Deniyaya (S) $11 . \mathrm{XII} .73$

600. Galwewa (NCP) 6. XI. 72

601. Ganegama, Pelmadulla (Sab) 18. VIl. 72

602. Horana (W) 23. XII. 72

603. Kaitadi, Jaffina (N) 16. XII. 71

604. Rarainagar, Jaffna (N) 15. XII. 71

605. Kayts (N) 17. XII. $7 \mathbb{1}$

606. Kottawa, Near Galle (S) 9. XIII. 73

607. Mandativu (N) 17. XII. 71 .

608. Manipay (N) 17. XII. 71

609. Matale (C) 2. I. 65

610. Mullativu-Paranthan Road (N) 22. IV. 74

611. Narawila, Near Nattandiya (NWP) 28. XI. 73

612. Nugegođa, Gangodawila (W) 22. XII. 70;25. I. 71; 14. II. 71;24. II. 71; 4. MI. 71; 12. III. 71; 19. III. 71; 25. III. 71; 2.IV. 71;1.VI. 71;22. VI. 71; 30.VI. 71;15.VII. 71;22. VII. 71;10.X.71; 19. X. $71 ;$ 30.X. $71 ; 7$. VIII. $72 ; 21 . \mathbb{I X} .72$

613. Pandeteruppu, Jaffina (N) 16. XII. 72

614. Padeniya (NWP) 17. XIII. 72

614.1 Palai, Jafina (N)

615. Pelmadulla, Ganegama (Sab) 19. VII. 72

516. Ratnapura (Sab) 19. XIII. 72

616.1 Ratnapura, Helanda, disused well in ricefield (Sab) 1E. VIII. 72

617. Tabbowa (NWP) 3. V. 72

618. Vaddukoddai (N) 14. XII. 71 
7. Miscellameous Habitals

70. Angunuwila, Culvert (NWP) 15. VI. 74

71.?

to Anuradhapura, Roadside ditches (NCP) 3. I. $65 ; 4$. I. 65

72. $\}$

73. Badulla (Legawatte estate), small water collection (Uva) 18. VIII. 72

74. Balangoda, disused well (UVa) 18. VIII. 72

75. Balangoda, drinking well (Uva) 16. XII. 73

76. Balangoda, small water collection (Uva) 15. VIII. 72

77. Battuluoya (Near Na-Eliya) we (MWP) 25. VIII. 72

78. Battuluoya, deep well (NWP) 28. VIII. 72

79. Battuluoya, disused shallow well (NWP) 28. XII. 72

700. Battuluoya, disused well (NWP) 28. VIII. 72

701. Ensalwatte, Deniyaya, pool (S) 11. XII. 73

702. Helanda, Ratnapura, stagnant ditch (Sab) 18. VIII. 72

703. Helanda, Ratnapura, disused well (Sab) 18. VIII. 72

704. Illuvankulam, small water collection (NWP) 13. VI. 73

705. Kallundai, Jaffna, fiood waters (N) 14. XII. 71

706. Kallundai, Jaffra, flood waters among plants (N) 14. XIII. $7 \mathbb{1}$

707. Kalpitiya, slightly saline pool (NWP) 15 . VI. 74

708. Kaludiyapokuna (Mihintaii) rockpool (NCP) 16. VI. 74

709. Kirillipone Near Colombo, Quarry for road metal (W) 23. XII. 72

710. Legawatte (Badulla), well (Uva) 8. X. 72

711. Mundel, roadside poois (NWP) 4. I. 65

712. Madurankuliya, roadside pools (NWP) 15. X. 72

713. Mandativu, temple bath $(\mathbb{N})$ 17. XII. 71

714.)

715. Marawila, ditches (NWP) 7. XII. 70;8. XII. 70;22. VIII. $72 ; 29$. XIII. 72

716.j

717. Meegoda, roadside pool (W) 23. XIII. 72

718. Nochchiyagama, Lunic water hole (NCP) 15. VI. 73

719. Nugegoda, deep well (W) 21. IX. 72

720. Nuwara Eliya (Hakgala road), wayside pool (C) 1. X. 72

721. Pelmadulıa, small water collection (Sab.) 17. VIII. 72

722. Puttalam, small water collection (NWP) 13. VI. 74.

723. Puttalam (Anuradhapura road) small wayside pool (NWP) 15. VI. 74

724. Puttalam, burrow pit (NWP) 4. I. 65

725. Puttalam (Anuradhapura road) culvert (NWP) 6. V. 73

726. Puttalam (Colombo road) roadside ditch (NWP) 15. VI. 74

727. Ratnapura, disused gem pit (Sab) 18. VIII. 72

728. Ratnapura, wayside ditch (Sab) 22. VIII. 72

729. Ratnapura, gem pit in use (Sab) 18. VIII. 72

730. Ratnapura, small water collection (Sab) 18. VIII. 72

730.1 Seruvil, Velanai, Jaffina, Rainpool (N) 1974

731. Tabbowa (Puttalam), culvert (NWP) 5. V. 73

732. Timbolketiya, near Thanamal wila, wayside pool (Uva) 7. VII. 74

733. Totapola, Near Punduloya, well (C) 22. XI. 73

733.1 Ullankulama (Kalpitiya) very small water hole (NWP) 15. VI. 74.

734. Vaddukoddai, wayside ditch (N) 14. XII. 71

735. Vellankadu (Kalpitiya) wayside ditch (NWP) 14. XII. 71 


\section{ADDENDUM}

These samples collected by Dr. D. G. Frey were examined after the analysis for species composition was completed TRepeats of previous localities mean additional samples :

1. Rivers and Sireams

14.1 Habarana-Polonnaruwa Road, Clear Stream (NCR) 3.I.65

POMdS

244.1 Peradeniya, Botanical Gardens (C) 2.I.65

244.2 Peradeniya, University Park (C) 2.1.65

249.1 Polonnaruwa Near Parakrama Samudra (NCP) 3.1.65

4. 筑eservoirs -300 hat

41. Castlereagh reservoir (C) 1.I.65

402. Minneriya tank (NCP) 3.1.65

405. Nalanda reservoir (C) 2.1 .65

407. Nuwarawewa, Anuradhapura (NCP) 3.I.65

409. Parakrama Samudra (NCP) 3.I.65 (2 samples)

420. Tabbowa tank (NWP) 4.1.65

5. IReservoirs $<300$ hin.

59. Colombo lake (Beira) (W) $31 . \times 1.64$

524. Kandy lake (C) 2.I.65 (2 samples)

561. Norton Bridge Reservoir (C) 1.I.65

563. Nuwara Eliya lake (C) 1.1 .65 (5 samples)

582. Thinipitiwewa, Near Chilaw (NWP) 4.I.65

585. Tissawewa (NCP) 4.1.65

5. Rieefields

609. IMatale (C) 2.I.65

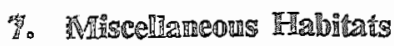

71. Anuradhapura, Roadside ditches (NCP) 3.I.65 